\title{
15
}

\section{Nonparametric Statistical Tests Comparing First Flush and Composite Samples from the National Stormwater Quality Database}

\author{
Alex Maestre, Robert Pitt and Derek Williamson
}

The University of Alabama and the Center of Watershed Protection, as part of an EPA 104(b)3 project, has collected and reviewed phase I NPDES (National Pollutant Discharge Elimination System) MS4 (Municipal Separate Storm Sewer System) stormwater data. The database contains more than 3700 event data sets from 66 municipalities in 17 States. In 1990, communities larger than 100,000 were required to monitor and control the pollutants that reach surface waters from stormwater runoff. Some communities collected grab samples during the first 30 minutes of the event to evaluate the "first flush" effect in contrast to the flow weighted composite samples.

There were 417 paired samples representing both first flush and composite samples from eight communities, mostly located in the southeast USA. Box and probability plots were prepared for 22 constituents including TSS, TDS, $\mathrm{BOD}_{5}, \mathrm{COD}$ among others. Nonparametric statistical analyses were used to measure differences between sample sets. This chapter shows the results of this preliminary analysis, including the effects of storm size and changes in land use. First flush effect was not present in all the land uses, and certainty not for all constituents. More detailed analyses will be performed as additional data are received.

\footnotetext{
Maestre, A., R.E. Pitt and D. Williamson. 2004. "Nonparametric Statistical Tests Comparing First Flush and Composite Samples from the National Stormwater Quality Database." Journal of Water Management Modeling R220-15. doi: 10.14796/JWMM.R220-15.

(c) CHI 2004 www.chijournal.org ISSN: 2292-6062 (Formerly in Innovative Modeling of Urban Water Systems. ISBN: 0-9683681-9-0)
} 


\subsection{Introduction}

The NPDES MS4 Stormwater was developed by EPA in response to the United States Congress to protect United States' receiving waters from contaminated stormwater discharges. In 1972, the Congress passed the Federal Water Pollution Control Act (CWA) expanding the federal role of water pollution control. Some of the effects of the CWA were to increase the federal funding for construction of publicly owned wastewater treatment works (POTW), and to develop community participation and a permit for each point discharge, among other activities. The NPDES established effluent guidelines for point discharges that contaminate the nation's water.

The first stormwater regulation was issued in 1973 (38 FR 13530, May 22), but EPA believed that the traditional end-of-pipe controls used for process discharges and treatment works could not be used to control stormwater pollution. In addition, it would require a tremendous effort to issue NPDES permits for each of the stormwater sources in the United States. The initial stormwater regulations were developed for large municipalities $(>100,000$ population) and for certain industrial categories. Current regulations associated with Phase II of the stormwater permit program now require stormwater management for all urban areas in the US.

The CWA of 1972 provided an important tool for communities. Section 208 provided the capability to implement stormwater management plans at the regional level. The task was welcomed by planning offices, which in some cases received advice from the U.S. Army Corps of Engineers. In 1976, EPA enlarged the planning initiative through the Section 208: Areawide Assessment Procedures Manual. However, in the late 1970s, some problems arose with the 208 planning projects due to inadequate data and lack of technological development (Whipple, 1980, cited by Pitt et al, 1999).

Between 1978 and 1983, EPA conducted the National Urban Runoff Program (NURP) that sought to determine water quality from separate storm sewers for different land uses. This program studied 81 outfalls at 28 sites, monitoring approximately 2300 storm events (EPA, 1983).

NURP is still an important reference for water quality characteristics of urban stormwater; however, there are other important studies that characterize stormwater pollutant generation. The USGS created a database with more than 1100 storms at 98 sites in 20 metropolitan areas as part of their monitoring for phase I communities (Smullen and Cave, 2003)

In 1987, the amendments to the CWA established a two-phase program to regulate 13 classes of stormwater discharges. Two of these classifications 
were discharges from large and medium MS4s. A large MS4 serves an urban population of 250,000 or more, while a medium MS4 serves communities between 100,000 and 250,000. EPA set up a permit strategy for communities complying with NPDES requirements. Monitoring data from this program have been included in some databases. The CDM National Stormwater Quality database included 816 NPDES storm events in a database that includes approximately 3100 total events. The Rouge River National Wet Weather Demonstration Program office in Detroit included their NPDES data in their database (Smullen and Cave, 2003). Recently EPA granted the University of Alabama and the Center of Watershed Protection funding to collect and evaluate NPDES MS4 municipal stormwater permits. By the end of 2002 this project had collected 3757 storm events from 66 agencies and municipalities in 17 states. This database (National Stormwater Quality Database, NSQD) includes geographic and seasonal information that can be useful for various analyses (Pitt et al, 2003).

Sample collection during some of the NPDES MS4 phase I permits required a grab and a composite sample. A grab sample was taken during the first 30 min of discharge, and a flow-weighted composite sample for the entire time of discharge. The initial grab sample was used for the analysis of the "first flush effect," assuming that most of the pollutants are discharged during the first period of runoff. The composite sample was obtained with aliquots collected about every 15 to $20 \mathrm{~min}$ for at least $3 \mathrm{~h}$, or until the event ended.

\subsection{First Flush}

First flush refers to an assumed elevated load of pollutants discharged in the beginning of a runoff event. The first flush effect has been observed more often in small catchments than in large catchments (Thompson et al, 1995, cited by WEF and ASCE 1998). In one case, large catchments ( $>162$ ha, 400 acres) had the highest concentrations observed at the times of flow peak (Soeur, et al. 1994; Brown et al. 1995). The presence of a first flush also has been reported to be associated with runoff duration by the City of Austin, Texas (reported by Swietlik et al., 1995). Peak pollutant concentrations can occur after the peak discharge, thus some pollutant discharges can be significant for events longer than the time of concentration (Ellis, 1986). Adams and Papa (2000), and Deletic (1998) both concluded that the presence of a first flush depends on numerous site and rainfall characteristics. 
In this chapter, pollutant characteristics are evaluated using the NSQD database for events that include information during the first $30 \mathrm{~min}$ and the composite sample, using nonparametric statistical methods. A better analysis can be performed by using the $\mathrm{M}(\mathrm{V})$ curves that relate the total mass discharge as a function of the total runoff volume; however, this procedure requires high resolution flow and concentration information. The NSQD database only contains concentration data from composite samples (and selected first-flush samples) and few flow data.

\subsection{Methodology}

A total of 417 storm events with paired first flush and composite samples were available from the NPDES MS4 database. The majority of the events were located in North Carolina (76.2\%), but some events were also from Alabama (3.1\%), Kentucky (13.9\%) and Kansas (6.7\%). Table 15.1 shows the events available for this analysis, separated by land use and community. All the events correspond to end-of the pipe samples in separate storm drainage systems.

Table 15.1 Preliminary number of storm events selected.

\begin{tabular}{|c|c|c|c|c|c|c|c|c|c|}
\hline State & Community & $\mathrm{CO}$ & FW & ID & IS & OP & $\mathrm{RE}$ & $\begin{array}{l}\text { Total } \\
\text { Events }\end{array}$ & $\%$ \\
\hline $\mathrm{AL}$ & $\begin{array}{l}\text { Jefferson } \\
\text { County }\end{array}$ & 5 & 2 & 0 & 0 & 0 & 6 & 13 & 3.1 \\
\hline $\mathrm{NC}$ & $\begin{array}{l}\text { City of } \\
\text { Charlotte }\end{array}$ & 8 & 0 & 8 & 0 & 3 & 16 & 35 & 8.4 \\
\hline NC & $\begin{array}{l}\text { City of } \\
\text { Fayetteville }\end{array}$ & 18 & 0 & 18 & 18 & 6 & 46 & 106 & 25.4 \\
\hline NC & $\begin{array}{l}\text { City of } \\
\text { Greensboro }\end{array}$ & 33 & 0 & 33 & 0 & 15 & 33 & 114 & 27.3 \\
\hline $\mathrm{KY}$ & $\begin{array}{l}\text { City of } \\
\text { Lexington }\end{array}$ & 12 & 3 & 2 & 0 & 2 & 18 & 37 & 8.9 \\
\hline $\mathrm{KY}$ & $\begin{array}{l}\text { City of } \\
\text { Louisville }\end{array}$ & 0 & 0 & 7 & 0 & 0 & 14 & 21 & 5.0 \\
\hline $\mathrm{NC}$ & $\begin{array}{l}\text { City of } \\
\text { Raleigh }\end{array}$ & 18 & 0 & 18 & 0 & 9 & 18 & 63 & 15.1 \\
\hline $\mathrm{KA}$ & $\begin{array}{l}\text { City of } \\
\text { Wichita }\end{array}$ & 7 & 0 & 7 & 0 & 0 & 14 & 28 & 6.7 \\
\hline $\begin{array}{c}\text { Total } \\
\text { Events }\end{array}$ & & 101 & 5 & 93 & 18 & 35 & 165 & 417 & \\
\hline$\%$ & & 24.2 & 1.2 & 22.3 & 4.3 & 8.4 & 39.6 & & 100 \\
\hline
\end{tabular}


The initial analyses were used to select the constituents and land uses that meet the requirements of the statistical comparison tests. Probability plots, box plots, concentration vs. precipitation and standard descriptive statistic calculations, were performed for 22 constituents for each land use, and all land uses combined. Nonparametric statistical analyses were performed after the initial analyses. Mann Whitney and Fligner-Policello test were most commonly used. Minitab and Systat statistical programs, along with Word and Excel macros, were used during the analysis.

\subsubsection{Initial Analysis}

One of the conclusions of the NURP program was that most of the constituents in stormwater generally follow a log-normal distribution, especially between the 5 th and 95 th percentiles (EPA, 1983). This was validated using probability plots during the initial analyses. Results from first flush and composite samples were log-transformed, for different pollutant types, in each land use category.

Figure 15.1 shows initial statistical results for both phosphorus and COD. Elevated first flush concentrations were evident for COD compared to phosphorus. Probability plots provide useful information about the characteristics of the sample population. Figure 15.1 is an example for total phosphorus observations from the open space land use. Both sample sets follow a lognormal distribution because most of the points lie on a straight line. The slopes of the lines are different, indicating unequal variances. Different methods having different detection limits were used by the different communities. In this case, about $40 \%$ of the first flush samples did not have detected concentrations for phosphorus, while about $20 \%$ of the composite samples had non-detected phosphorus concentrations. This plot also indicated that the median concentration of the composite samples is almost twice the median value for the first flush samples.

The next initial analysis used box plots. These plots also represent the distribution of the data, but only show the detectable concentrations. The middle line inside the box represents the median of the data. The top of the box represents the third quartile, and the bottom the first quartile. The whiskers are extended from the $5^{\text {th }}$ to the $95^{\text {th }}$ percentile limits. Values outside these limits are represented with asterisks. The exclusion of the non detected values changes the median of the data compared to the probability plots. In this example, both of the medians are similar, in contrast with the results of the probability plot. In this example, the variability of the first flush observations is also seen to be larger than the composite data set. 
Probability Plot

Phosphorus Total (mg/L) - Open Space

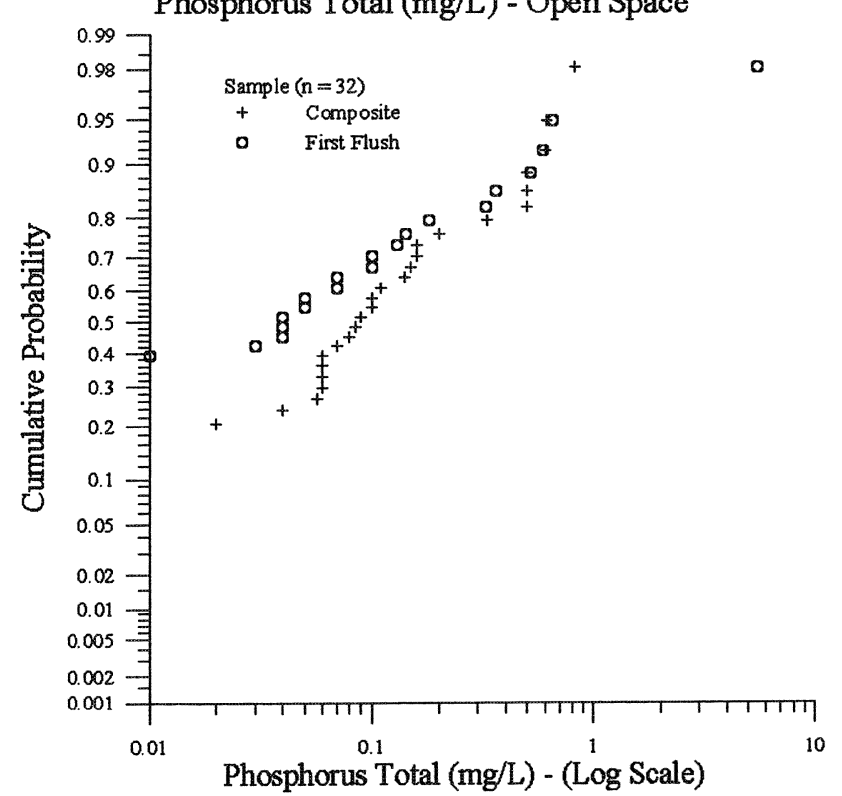

Box-Whisker Plot

Phosphorus Total (mg/L) - Open Space

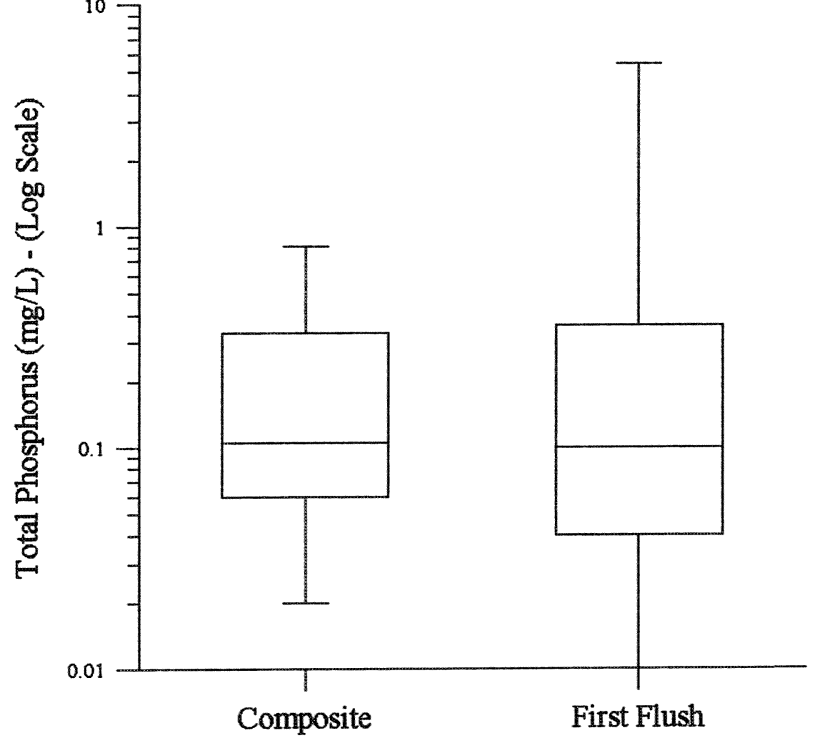

Figure 15.1 Cumulative probability and box-whisker plots. 

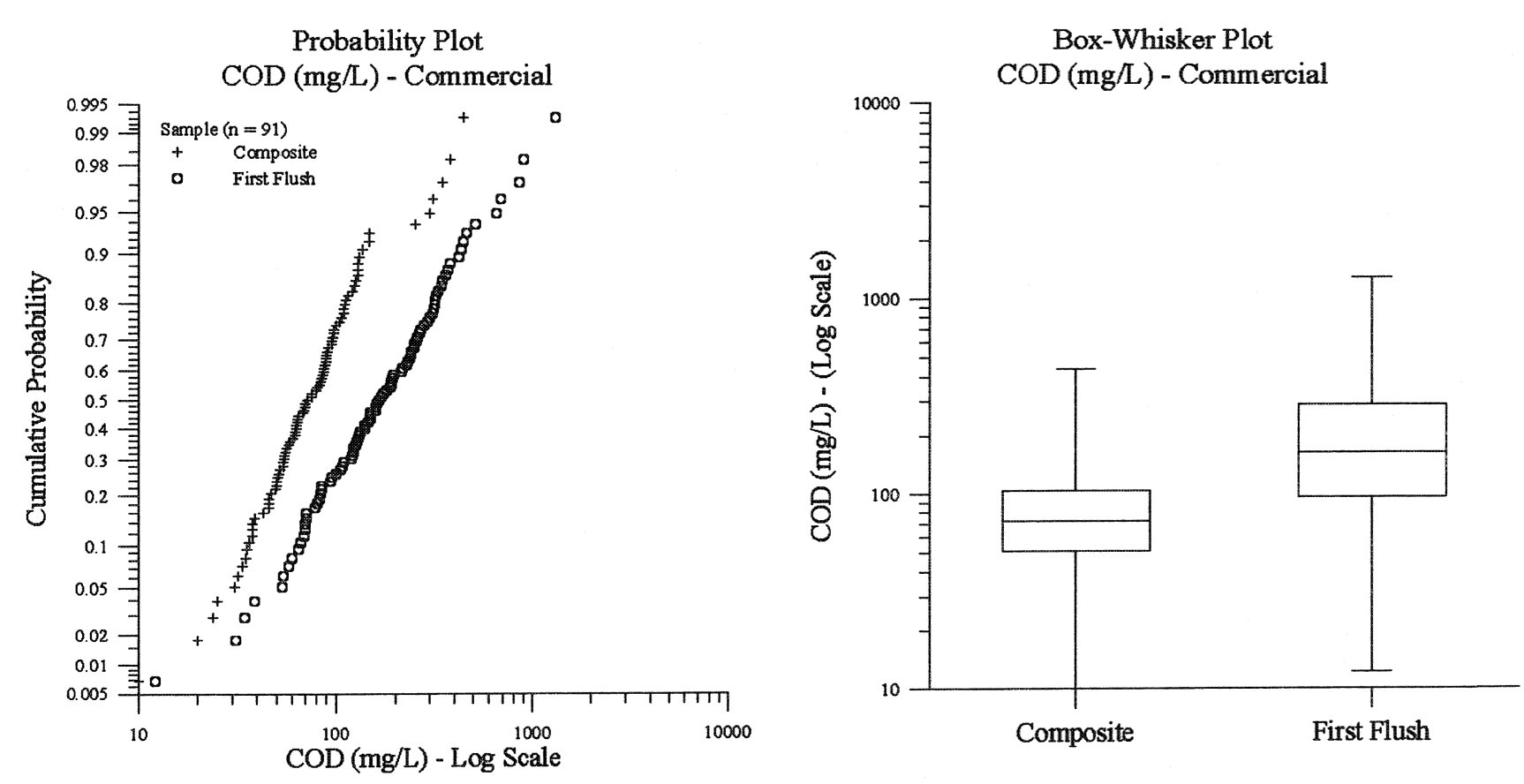

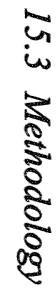

Figure 15.1 Cumulative probability and box-whisker plots (continued). 
Table 15.2 Initial analysis.

\begin{tabular}{|c|c|c|c|c|c|c|}
\hline Constituent & Commercial & Industrial & Institutional & Open Space & Residential & ALL \\
\hline Turbidity, NTU & Selected & No data & No data & Ned & Selected & Selected \\
\hline pH, S.U. & Selected & Selected & No data & Ned & Selected & Selected \\
\hline BOD5, mg/L & Selected & Selected & Box plot FF > Composite & Selected & Selected & Selected \\
\hline $\mathrm{COD}, \mathrm{mg} / \mathrm{L}$ & Selected & Selected & Selected & Selected & Selected & Selected \\
\hline $\mathrm{TSS}, \mathrm{mg} / \mathrm{L}$ & Selected & Selected & Selected & Selected & Selected & Selected \\
\hline $\mathrm{TDS}, \mathrm{mg} / \mathrm{L}$ & Selected & Selected & Selected & Selected & Selected & Selected \\
\hline $\mathrm{O \& G}, \mathrm{mg} / \mathrm{L}$ & Selected & Ned & Ned & Ned & Selected & Selected \\
\hline Fecal Coliform, col/100mL & Selected & Ned & Ned & Ned & Selected & Selected \\
\hline Fecal Streptococcus, col/100 mL & Selected & Ned & Ned & Ned & Selected & Selected \\
\hline Ammonia, mg/L & Selected & Selected & Box plot FF $>$ composite & Ned & Selected & Selected \\
\hline $\mathrm{NO}_{2}+\mathrm{NO}_{3} \mathrm{mg} / \mathrm{L}$ & Selected & Selected & Selected & Selected & Selected & Selected \\
\hline $\mathrm{N}$ Total, $\mathrm{mg} / \mathrm{L}$ & Selected & Selected & Ned & Selected & Selected & Selected \\
\hline $\mathrm{TKN}, \mathrm{mg} / \mathrm{L}$ & Selected & Selected & Box plot $\mathrm{FF}>$ composite & Selected & Selected & Selected \\
\hline P Total, mg/L & Selected & Selected & Selected & Selected & Selected & Selected \\
\hline P Dissolved, mg/L & Selected & Selected & Selected & Selected & Selected & Selected \\
\hline Ortho-P, mg/L & Ned & Selected & Ned & Ned & Selected & Selected \\
\hline Cadmium Total, $\mu \mathrm{g} / \mathrm{L}$ & Selected & Selected & Ned & Selected & Selected & Selected \\
\hline Chromium Total, $\mu \mathrm{g} / \mathrm{L}$ & Selected & Selected & Ned & Selected & Selected & Selected \\
\hline Copper Total, $\mu \mathrm{g} / \mathrm{L}$ & Selected & Selected & Selected & Selected & Selected & Selected \\
\hline Lead Total, $\mu \mathrm{g} / \mathrm{L}$ & Selected & Selected & Selected & Selected & Selected & Selected \\
\hline Mercury, $\mu \mathrm{g} / \mathrm{L}$ & Ned & Ned & Ned & Ned & Ned & Ned \\
\hline Nickel, $\mu \mathrm{g} / \mathrm{L}$ & Selected & Selected & Ned & Ned & Selected & Selected \\
\hline Zinc, $\mu \mathrm{g} / \mathrm{L}$ & Selected & Selected & Selected & Selected & Selected & Selected \\
\hline
\end{tabular}


Descriptive statistics for each constituent and land use were calculated to determine if the distributions were symmetrical and if they had the same variance (see appendix). This evaluation is needed to select the most appropriate statistical tests. In some conditions, the number of sample pairs was not large enough to allow further analyses. Table 15.2 shows the results of the initial analysis. Samples having log-normal probability distributions and sufficient data sets were selected for further analyses.

\subsubsection{Nonparametric Statistical Analysis}

The last step in the initial analysis was to obtain descriptive statistics of each land use and constituent. The skewness and the standard error of skewness are important for some statistical analyses. A distribution is symmetrical if the skewness divided by the standard error of skewness is smaller than two (Systat, 1997). Another method is to check if the zero value is included in the $95 \%$ confidence interval for the skewness. If it is, the distribution is not skewed.

The Mann-Whitney and Fligner-Policello nonparametric tests were selected to determine if there were statistically significant differences between the first flush and composite data sets for each landuse and constituent. These tests require only data symmetry, or normality, to evaluate the hypothesis. The null hypothesis in the analysis is that the median concentrations of the first flush and composite data sets were the same. The alternative hypothesis is that the medians are different (the first-flush sample median concentrations could be either greater or smaller that the composite sample median concentrations), with a confidence of at least $95 \%$.

Figure 15.2 shows the steps that were followed during the nonparametric analysis. The most useful test was the Fligner-Policello test. This test requires independent random samples symmetric about the medians for each data set. The advantage of this test is that does not require normality or the same variance in each data set (Fligner and Policello, 1981). The U statistic and the p-value are shown in the attached appendix for some constituents. Chakraborti (2003) presents a definition and explanation of the Mann-Whitney $U$ test. All calculations are included in the extended version posted in the http://www.bama.ua.edu/ $\sim$ maest001/Research/NSQD/NSQDmain.shtml. P-values smaller than 5\% $(<0.05)$ indicate that the first flush and composite sample sets have different median concentrations at the $95 \%$, or greater, confidence level.

If the number of samples is large, and the distributions are normal and have the same variance, a paired Student's t-test is usually a better test to evaluate the hypothesis and support the results of the Fligner-Policello test. To verify that 


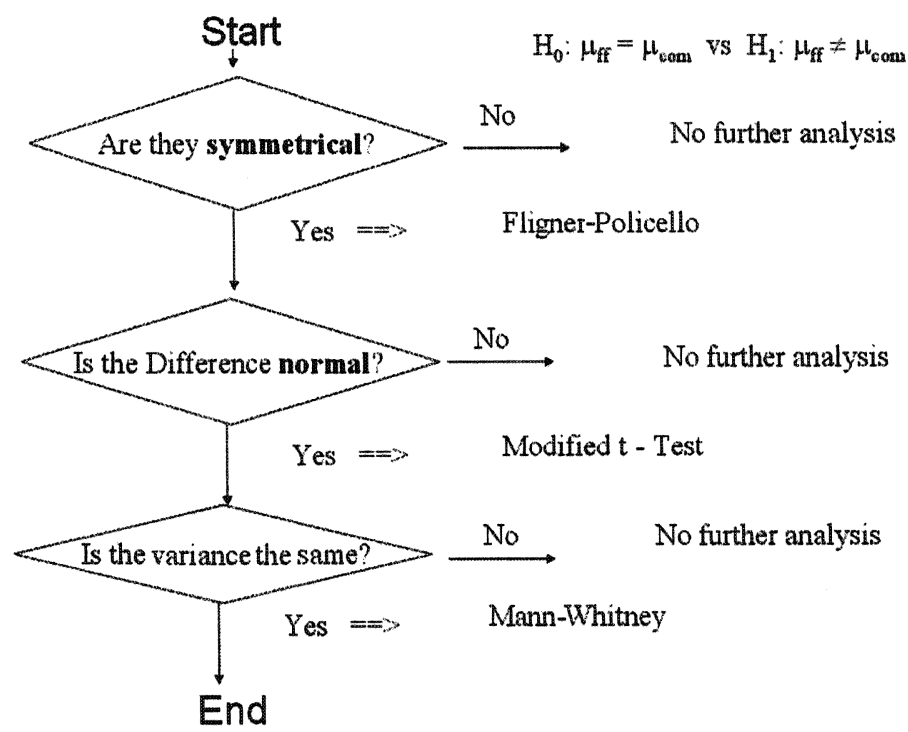

Figure 15.2 Analysis flow chart.

the data distributions are normal, the Anderson-Darling normality test was used (Kottegoda and Rosso, 1997). This method uses an empirical cumulative distribution function to check normality. In the attached appendix, the p-value of the paired difference is shown. P-values larger than 5\% (>0.05) indicate that the normality requirement was met, at the $95 \%$ or greater confidence level.

Finally, if the first flush and composite sample distributions are symmetrical (but not necessarily normal), and if they have the same variance, the MannWhitney test can be used. If the p-value is larger than 5\% (>0.05), the medians of the sample distribution are assumed to be the same, at the $95 \%$ or greater confidence level. Results are shown in the attached appendix.

The preferred test would be the Student's $t$ test, if the sample characteristics warrant, followed by the Mann-Whitney test and finally the FlignerPolicello test.

The appendix also shows the number of paired samples for each constituent and land use. The selected cases are only for pairs with concentration values above the detection limits. The ratios between the first flush and composite sample medians are also shown. Commercial and residential areas have the highest ratios for most constituents. The smallest ratios were found for open space sites. 


\subsection{Results}

Around $83 \%$ of the possible paired cases were successfully evaluated; the remaining cannot be evaluated because the data set did not have enough paired data, or were not symmetrical. Table 15.3 shows the results of the analysis. The " $\neq$ " sign indicates that the medians of the first flush and the composite data set are different. The " $=$ " sign indicates that there is not enough information to reject the null hypothesis at the desired level of confidence (at least at the $95 \%$ level). Events without enough data are represented with an "X".

Also shown on this table are the ratios of the medians of the first flush and the composite data sets for each constituent and land use. Generally, a statistically significant first flush is associated with a median concentration ratio of about 1.4, or greater (the exceptions are where the number of samples in a specific category is much smaller). The largest ratios are about 2.5 , indicating that for these conditions, the first flush sample concentrations are about 2.5 times greater than the composite sample concentrations. More of the larger ratios are found for the commercial and institutional land use categories, areas where larger paved areas are likely to be found. The smallest ratios are associated with the residential, industrial, and open spaces land uses, locations where there may be larger areas of unpaved surfaces.

Results indicate that for $55 \%$ of the evaluated cases, the median of the first flush data set were different than the composite sample set. In the remaining $45 \%$ of the cases, both medians were likely the same, or the concentrations were possibly greater later in the events.

About $70 \%$ of the constituents in the commercial land use category had elevated first-flush concentrations, while about $60 \%$ of the constituents in the residential, institutional and the mixed (mostly commercial and residential) land use categories had elevated first flushes, and about $45 \%$ of the constituents in the industrial land use category had elevated first flushes. In contrast, no constituents were found to have elevated first-flushes in the open space category.

$\mathrm{COD}, \mathrm{BOD}_{5}$, TDS, TKN and $\mathrm{Zn}$ all had first flushes in all areas (except for the open space category). In contrast, turbidity, $\mathrm{pH}$, fecal coliform, fecal streptococcus, total $\mathrm{N}$, dissolved and ortho-P never showed a statistically significant first flush in any category. The conflict with $\mathrm{TKN}$ and total $\mathrm{N}$ implies that there may be other factors involved in the identification of first flushes besides land use. If additional paired data becomes available during later project periods, it may be possible to extend this analysis to consider rain effects, drainage area, and geographical location. 
Table 15.3 Presence of significant first flushes (ratio of first flush to composite median concentrations).

\begin{tabular}{|c|c|c|c|c|c|c|c|c|c|c|c|c|}
\hline \multirow[t]{2}{*}{ Parameter } & \multicolumn{4}{|c|}{ Commercial } & \multicolumn{4}{|c|}{ Industrial } & \multicolumn{4}{|c|}{ Institutional } \\
\hline & $\mathrm{n}$ & sc & $\mathbf{R}$ & ratio & $\mathbf{n}$ & $\mathrm{sc}$ & $\mathrm{R}$ & ratio & $\mathbf{n}$ & sc & $\mathbf{R}$ & ratio \\
\hline Turbidity, NTU & 11 & 11 & $=$ & 1.32 & & & $x$ & & & & $x$ & \\
\hline pH, S.U. & 17 & 17 & $=$ & 1.03 & 16 & 16 & $=$ & 1.00 & & & $x$ & \\
\hline $\mathrm{COD}, \mathrm{mg} / \mathrm{L}$ & 91 & 91 & $\neq$ & 2.29 & 84 & 84 & $\neq$ & 1.43 & 18 & 18 & $\neq$ & 2.73 \\
\hline TSS, mg/L & 90 & 90 & $\neq$ & 1.85 & 83 & 83 & $=$ & 0.97 & 18 & 18 & $\neq$ & 2.12 \\
\hline BOD5, mg/L & 83 & 83 & $\neq$ & 1.77 & 80 & 80 & $\neq$ & 1.58 & 18 & 18 & $\neq$ & 1.67 \\
\hline $\mathrm{TDS}, \mathrm{mg} / \mathrm{L}$ & 82 & 82 & $\neq$ & 1.83 & 82 & 81 & $\neq$ & 1.32 & 18 & 18 & $\neq$ & 2.66 \\
\hline O\&G, mg/L & 10 & 10 & $\neq$ & 1.54 & & & $x$ & & & & $x$ & \\
\hline Fecal Coliform, col/100mL & 12 & 12 & $=$ & 0.87 & & & $\mathbf{x}$ & & & & $\mathrm{x}$ & \\
\hline Fecal Streptococcus, col/100 mL & 12 & 11 & $=$ & 1.05 & & & $\mathbf{x}$ & & & & $\mathrm{X}$ & \\
\hline Ammonia, mg/L & 70 & 52 & $\neq$ & 2.11 & 40 & 33 & $=$ & 1.08 & 18 & 16 & $\neq$ & 1.66 \\
\hline $\mathrm{NO}_{2}+\mathrm{NO}_{3}, \mathrm{mg} / \mathrm{L}$ & 84 & 82 & $\neq$ & 1.73 & 72 & 71 & $\neq$ & 1.31 & 18 & 18 & $\neq$ & 1.70 \\
\hline $\mathrm{N}$ Total, $\mathrm{mg} / \mathrm{L}$ & 19 & 19 & $=$ & 1.35 & 19 & 16 & $=$ & 1.79 & & & $\mathrm{X}$ & \\
\hline $\mathrm{TKN}, \mathrm{mg} / \mathrm{L}$ & 93 & 86 & $\neq$ & 1.71 & 77 & 76 & $\neq$ & 1.35 & & & $x$ & \\
\hline P Total, mg/L & 89 & 77 & $\neq$ & 1.44 & 84 & 71 & $=$ & 1.42 & 17 & 17 & $=$ & 1.24 \\
\hline P Dissolved, mg/L & 91 & 69 & $=$ & 1.23 & 77 & 50 & $=$ & 1.04 & 18 & 14 & $=$ & 1.05 \\
\hline Ortho-P, mg/L & & & $x$ & & 6 & 6 & $=$ & 1.55 & & & $x$ & \\
\hline Cadmium Total, $\mu \mathrm{g} / \mathrm{L}$ & 74 & 48 & $\neq$ & 2.15 & 80 & 41 & $=$ & 1.00 & & & $\mathrm{X}$ & \\
\hline Chromium Total, $\mu \mathrm{g} / \mathrm{L}$ & 47 & 22 & $\neq$ & 1.67 & 54 & 25 & $=$ & 1.36 & & & $x$ & \\
\hline Copper Total, $\mu \mathrm{g} / \mathrm{L}$ & 92 & 82 & $\neq$ & 1.62 & 84 & 76 & $\neq$ & 1.24 & 18 & 7 & $=$ & 0.94 \\
\hline Lead Total, $\mu \mathrm{g} / \mathrm{L}$ & 89 & 83 & $\neq$ & 1.65 & 84 & 71 & $\neq$ & 1.41 & 18 & 13 & $\neq$ & 2.28 \\
\hline Nickel, $\mu \mathrm{g} / \mathrm{L}$ & 47 & 23 & $\neq$ & 2.40 & 51 & 22 & $=$ & 1.00 & & & $x$ & \\
\hline Zinc, $\mu \mathrm{g} / \mathrm{L}$ & 90 & 90 & $\neq$ & 1.93 & 83 & 83 & $\neq$ & 1.54 & 18 & 18 & $\neq$ & 2.48 \\
\hline
\end{tabular}


Table 15.3 Presence of significant first flushes (ratio of first flush to composite median concentrations) continued.

\begin{tabular}{|c|c|c|c|c|c|c|c|c|c|c|c|c|}
\hline \multirow[t]{2}{*}{ Parameter } & \multicolumn{4}{|c|}{ Open Space } & \multicolumn{4}{|c|}{ Residential } & \multicolumn{4}{|c|}{ All Combined } \\
\hline & $\mathrm{n}$ & sc & $\mathrm{R}$ & ratio & $\mathrm{n}$ & sc & $\mathrm{R}$ & ratio & $\mathrm{n}$ & sc & $\mathrm{R}$ & ratio \\
\hline Turbi dity, NTU & & & $x$ & & 12 & 12 & $=$ & 1.24 & 26 & 26 & $=$ & 1.26 \\
\hline pH, S.U. & & & $x$ & & 26 & 26 & $=$ & 1.01 & 63 & 63 & $=$ & 1.01 \\
\hline $\mathrm{COD}, \mathrm{mg} / \mathrm{L}$ & 28 & 28 & $=$ & 0.67 & 140 & 140 & $\neq$ & 1.63 & 363 & 363 & $\neq$ & 1.71 \\
\hline TSS, mg/L & 32 & 32 & $=$ & 0.95 & 144 & 144 & $\neq$ & 1.84 & 372 & 372 & $\neq$ & 1.60 \\
\hline $\mathrm{BOD} 5, \mathrm{mg} / \mathrm{L}$ & 28 & 28 & $=$ & 1.07 & 133 & 133 & $\neq$ & 1.67 & 344 & 344 & $\neq$ & 1.67 \\
\hline TDS, mg $\mathrm{L}$ & 31 & 30 & $=$ & 1.07 & 137 & 133 & $\neq$ & 1.52 & 354 & 342 & $\neq$ & 1.55 \\
\hline O\&G, mg/L & & & $x$ & & & & $x$ & & 18 & 14 & $\neq$ & 1.60 \\
\hline Fecal Coliform, col $/ 100 \mathrm{~mL}$ & & & $x$ & & 10 & 9 & $=$ & 0.98 & 22 & 21 & $=$ & 1.21 \\
\hline Fecal Streptococcus, col/100 mL & & & $x$ & & 11 & 8 & $=$ & 1.30 & 26 & 22 & $=$ & 1.11 \\
\hline Ammonia, $\mathrm{mg} / \mathrm{L}$ & & & $x$ & & 119 & 86 & $\neq$ & 1.36 & 269 & 190 & $\neq$ & 1.54 \\
\hline $\mathrm{NO}_{2}+\mathrm{NO}_{3}, \mathrm{mg} / \mathrm{L}$ & 30 & 21 & $=$ & 0.96 & 121 & 118 & $\not$ & 1.66 & 324 & 310 & $\neq$ & 1.50 \\
\hline $\mathrm{N}$ Total, $\mathrm{mg} / \mathrm{L}$ & 6 & 6 & $=$ & 1.53 & 31 & 30 & $=$ & 0.88 & 77 & 73 & $=$ & 1.22 \\
\hline TKN, mg/L & 32 & 14 & $=$ & 1.28 & 131 & 123 & $\neq$ & 1.65 & 335 & 301 & $\neq$ & 1.60 \\
\hline P Total, mg/L & 32 & 20 & $=$ & 1.05 & 140 & 128 & $\neq$ & 1.46 & 363 & 313 & $\neq$ & 1.45 \\
\hline P Dissolved, mg/L & 32 & 14 & $=$ & 0.69 & 130 & 105 & $\neq$ & 1.24 & 350 & 254 & $=$ & 1.07 \\
\hline Ortho-P, $\mathrm{mg} / \mathrm{L}$ & & & $x$ & & 14 & 14 & $=$ & 0.95 & 22 & 22 & $=$ & 1.30 \\
\hline Cadmium Total, $\mu \mathrm{g} / \mathrm{L}$ & 30 & 15 & $=$ & 1.30 & 123 & 33 & $\neq$ & 2.00 & 325 & 139 & $\neq$ & 1.62 \\
\hline Chromium Total, $\mu \mathrm{g} / \mathrm{L}$ & 16 & 4 & $=$ & 1.70 & 86 & 31 & $=$ & 1.24 & 218 & 82 & $\neq$ & 1.47 \\
\hline Copper Total, $\mu \mathrm{g} / \mathrm{L}$ & 30 & 22 & $=$ & 0.78 & 144 & 108 & $\neq$ & 1.33 & 368 & 295 & $\neq$ & 1.33 \\
\hline Lead Total, $\mu \mathrm{g} / \mathrm{L}$ & 31 & 16 & $=$ & 0.90 & 140 & 93 & $\neq$ & 1.48 & 364 & 278 & $\neq$ & 1.50 \\
\hline Nickel,$\mu g / \mathrm{L}$ & & & $x$ & & 83 & 18 & $=$ & 1.20 & 213 & 64 & $\neq$ & 1.50 \\
\hline Zinc, $\mu \mathrm{g} / \mathrm{L}$ & 21 & 21 & $=$ & 1.25 & 136 & 136 & $\neq$ & 1.58 & 350 & 350 & $\neq$ & 1.59 \\
\hline
\end{tabular}

Note: $\mathrm{n}=$ number of events. $\mathrm{sc}=$ number of selected ev ents with detected $\mathrm{v}$ alues. $\mathrm{R}=$ result: not enough data $(\mathrm{X})$; not enough

evidence to conclude that median values are different $\Leftrightarrow$; median values are different $(\neq)$. 


\subsection{Discussion}

It is expected that peak concentrations generally occur during periods of peak flows (and highest rain energy). On relatively small paved areas, however, it is likely that there will always be a short initial period of relatively high concentrations associated with washing off of the most available material (Pitt, 1987). This peak period of high concentrations may be overwhelmed by periods of high rain intensity that may occur later in the event. In addition, in more complex drainage areas, the routing of these short periods of peak concentrations may blend with larger flows and may not be noticeable. A first flush in a separate storm drainage system is therefore most likely to be seen if a rain occurs at relatively constant intensity over a paved area having a simple drainage system.

If the peak flow (and highest rain energy) occurs later in the event, then there likely will not be a noticeable first flush. However, if the rain intensity peak occurs at the beginning of the event, then the effect is exaggerated. Figure 15.3 shows an example storm in Lexington, Kentucky. Note that in this event there are two flow peaks, the first occurs one hour after the rain started, the second two hours later. If the concentrations remains the same during the entire event, the maximum load will occur during the later periods of maximum flow (the two peaks), and not during the initial period of the storm.

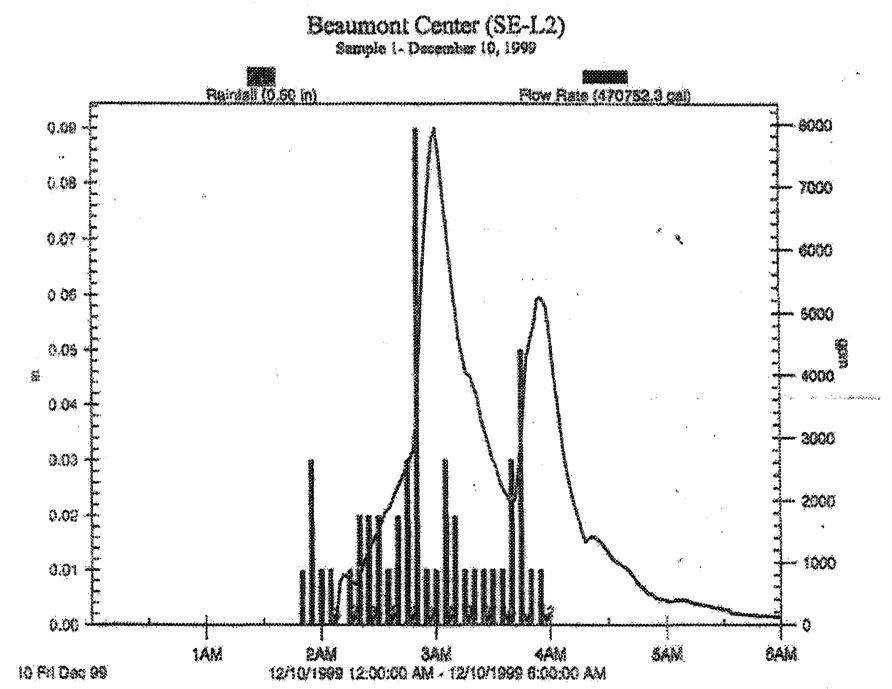

Figure 15.3 Hydrograph for a storm event. (Source: NPDES permit Lexington-KY 2000). $\left(1 \mathrm{in}=25.4 \mathrm{~mm}, 1 \mathrm{~m}^{3}=264.17 \mathrm{gal}\right)$. 
Another factor that needs to be considered is the source of the contaminants and how fast they travel through the watershed. Streets and pervious areas will contribute flow to the total area discharge before the pervious areas.

Figure 15.4 (Pitt, 1999) shows that for an example constant rainfall, the source area flow contribution changes for different rain conditions in a residential area. If the percentage of imperviousness is high, many of the constituents will be discharged faster. This observation agrees with the results observed from the statistical analysis. Commercial areas have a larger frequency of high concentrations at the beginning of the event in contrast to open space areas.

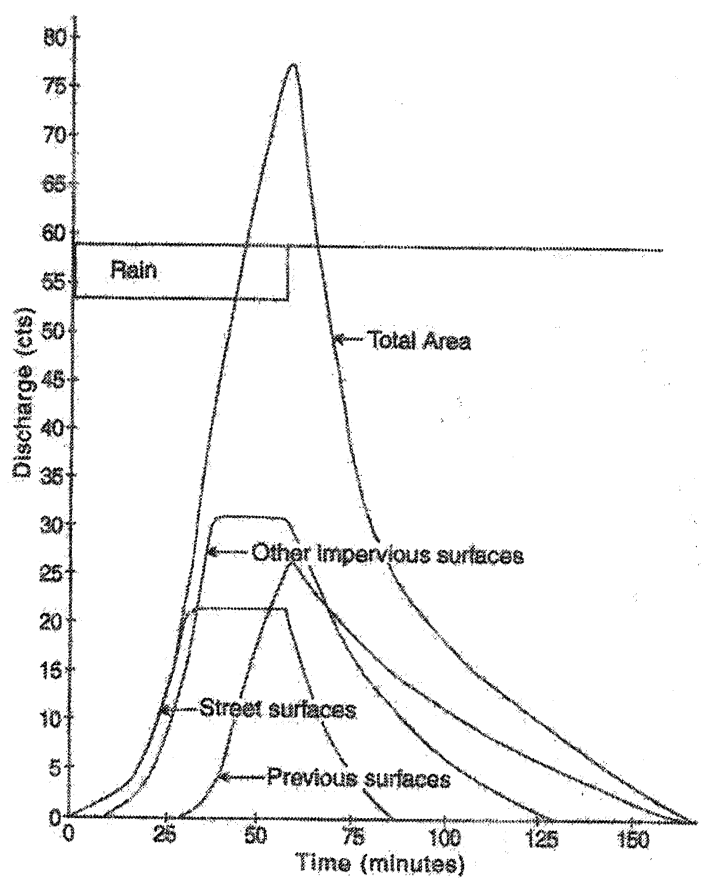

Figure 15.4 Contributing areas in urban watersheds (Pitt, 1999) $\left(1 \mathrm{~m}^{3} / \mathrm{s}=35.32 \mathrm{cfs}\right)$.

Figure 15.5 shows that for events $(<12 \mathrm{~mm}$, or $0.5 \mathrm{in})$ in this example medium density residential area, most of the runoff is generated by impervious areas. The average percentage of imperviousness for the monitoring sites was examined. Commercial areas had an average of $83 \%$ imperviousness, followed by industrial areas at $70 \%$ imperviousness. Institutional and residential land uses 


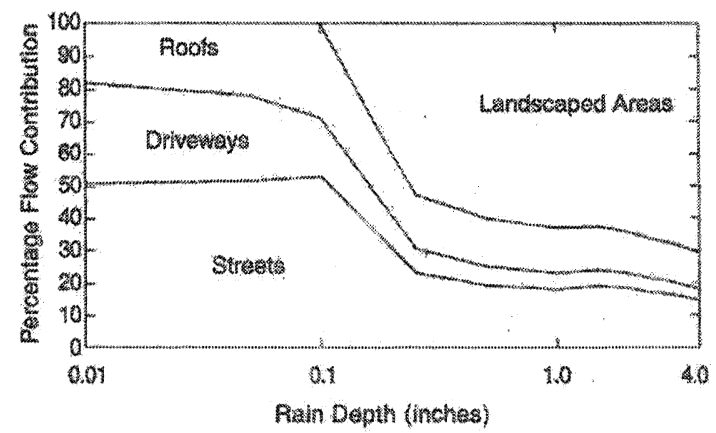

Figure 15.5 Contributing areas in urban watersheds (Pitt and Voorhees, 1995)(1 in $=25.4 \mathrm{~mm}$ ).

were very similar, with $45 \%$ and $42 \%$ imperviousness respectively. The open space land use category had the smallest imperviousness area, at about $4 \%$. As indicated in Figure 15.5, larger events can generate more runoff from previous areas than impervious areas. However, it is likely that most of the runoff during the MS4 monitoring activities was associated with the more common small events, and hence, impervious areas were more important.

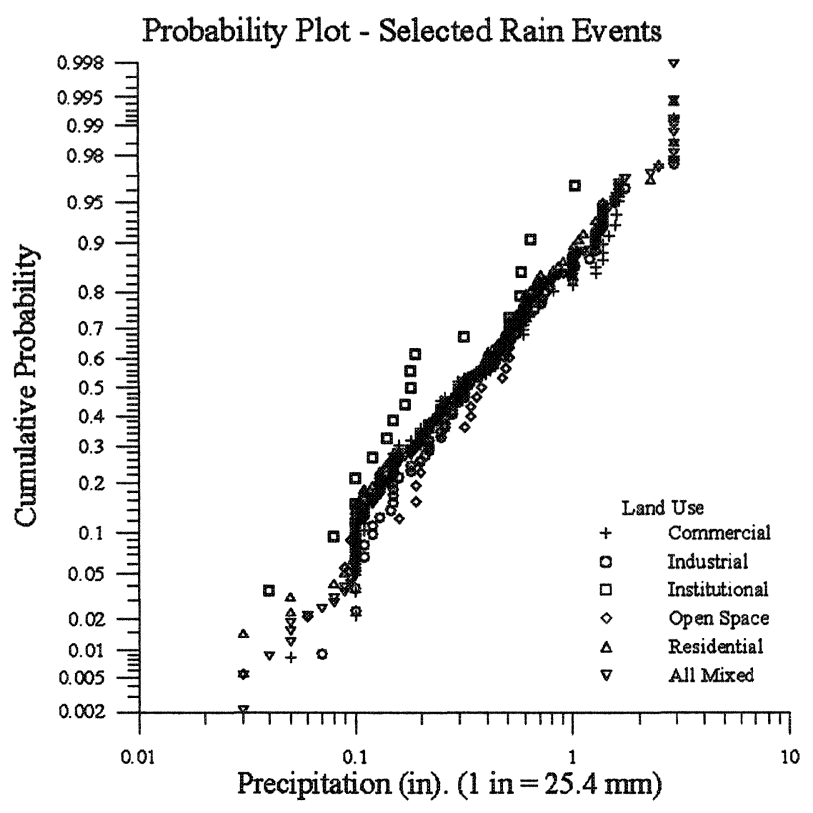

Figure 15.6a Probability plot of selected rain events. 




Figure 15.6b Box plot of the same selected rain events.

Probability plots of the precipitation associated with each monitored event for each land use category were prepared to see if there were any significant differences in the ranges of rains observed within each land use category.

Figure 15.6 shows that precipitation has the same distribution for almost all the different land uses. The institutional land use shows a slightly smaller median rain, but this is likely because of the small number of events observed in that land use category ( 18 events). The median precipitation observed during the monitoring at all land uses was about $8 \mathrm{~mm}(0.3 \mathrm{in})$, indicating the importance of the runoff from the impervious areas.

Finally the effect of the sampling duration must be considered. One of the recommendations during Phase I was to collect a sample during the first $30 \mathrm{~min}$ of the event, but that the composite only needed to be collected during the first $3 \mathrm{~h}$ or the complete event. Figure 15.7 shows an example case when these conditions can lead to inappropriate conclusions for longer events.

The twelve aliquots sampled during the first three hours are shown on the left side of Figure 15.7. On the right side of the figure, showing the complete event, the peak discharge occurred four hours after the event started, and was not represented in the sampling program. Not including the complete event in a monitoring program may lead to inappropriate conclusions. It is suggested that for stormwater monitoring, samples should be collected during the complete event and composited before laboratory analyses. 


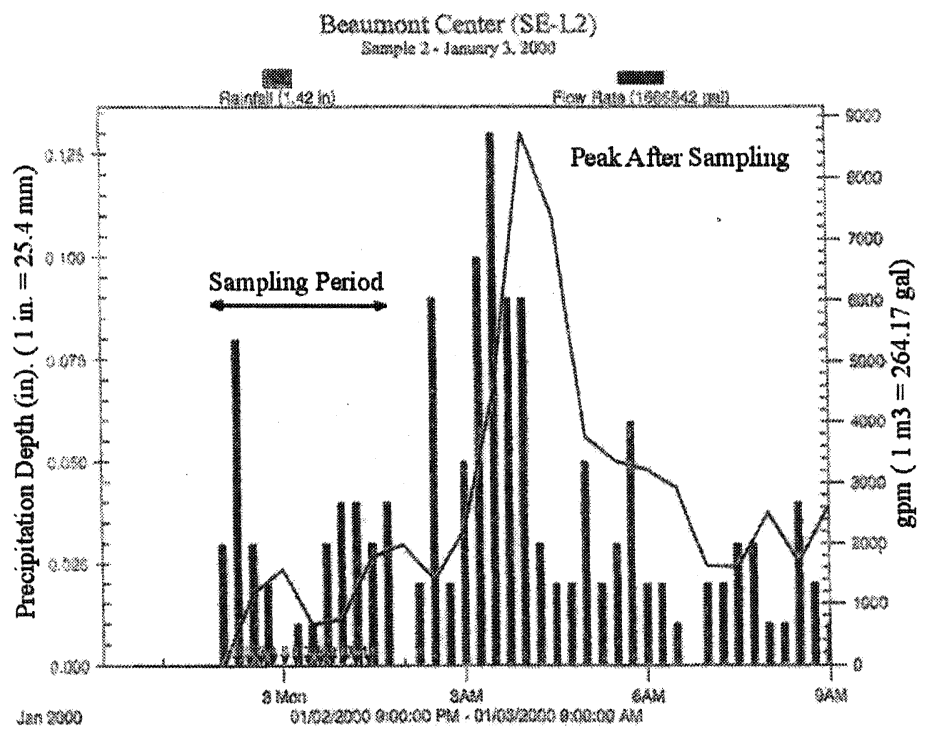

Figure 15.7 Example of an event with peaks after the sampling period. (Source: NPDES permit Lexington-KY, 2000).

Another sampling example was presented by Roa-Espinosa and Bannerman (1995) who collected samples from five industrial sites using five different monitoring methods. Table 15.4 shows the ranking of the best methods of sampling based in six criteria. In this table a value between one and five points is assigned to each criterion. Five points indicates that the method is excellent in the specific criterion. Rao-Espinosa and Bannerman concluded that many

Table 15.4 Ranking by methods of sampling (Roa-Espinosa, Bannerman, 1995).

\begin{tabular}{lcccccc}
\hline \multicolumn{1}{c}{ Criteria } & $\begin{array}{c}\text { Flow } \\
\text { Comp- } \\
\text { osite }\end{array}$ & $\begin{array}{c}\text { Time } \\
\text { Discrete }\end{array}$ & $\begin{array}{c}\text { Time } \\
\text { Comp- } \\
\text { osite }\end{array}$ & $\begin{array}{c}\text { Old } \\
\text { Source } \\
\text { Sample }\end{array}$ & $\begin{array}{c}\text { New } \\
\text { Source } \\
\text { Sample }\end{array}$ & $\begin{array}{c}\text { First } \\
30 \\
\text { min }\end{array}$ \\
\hline Site Selection & 1 & 1 & 1 & 5 & 5 & 3 \\
Cost & 1 & 1 & 3 & 5 & 5 & 5 \\
Technical difficulty & 1 & 1 & 3 & 5 & 5 & 5 \\
Accuracy & 5 & 5 & 4 & 1 & 5 & 1 \\
Reproducibility & 5 & 5 & 5 & 1 & 5 & 1 \\
Representativeness & 1 & 1 & 3 & 5 & 5 & 1 \\
Total Points & 14 & 14 & 19 & 22 & 30 & 16 \\
\hline
\end{tabular}


time-composite subsamples combined for a single composite analysis can provide improved accuracy compared to fewer samples associated with flowweighted sampling. They also found that time composite subsamples provide better results than samples collected during the first $30 \mathrm{~min}$ of the event.

\subsection{Conclusion}

A major goal of the present study is to provide guidance to stormwater managers and regulators. Especially important will be the use of these data as an updated benchmark for comparison with locally collected data. In addition, they may be useful for preliminary calculations when using the "simple method" for predicting mass discharges for unmonitored areas. These data can also be used as guidance when designing local stormwater monitoring programs (Burton and Pitt, 2002), especially when determining the needed sampling effort based on expected variations. Continuing studies will expand on these examples and will also investigate other stormwater data and sampling issues.

Investigation indicated that a first flush effect (increased concentrations at the beginning of an event) was not present in all the land uses, and certainly not for all constituents. Commercial and residential areas were more likely to show this phenomenon, especially if the peak rainfall occurred near the beginning of the event. It is expected that this effect will be more likely to occur in a watershed with a high level of imperviousness, but the data indicated first flushes less than $50 \%$ of the time for the most impervious areas.

Groups of constituents showed different behavior for different land uses. All the heavy metals evaluated showed higher concentrations at the beginning of the event in the commercial land use category. Similarly all the nutrients show a higher concentration in the residential land use except for total nitrogen and ortho-P. This phenomenon was not found in the bacteria analyses. None of the land uses showed a higher number of colonies during the beginning of the event. Conventional constituents showed elevated concentrations in commercial, residential and institutional land uses.

\subsection{Appendix}

Overleaf, Table 15.5 shows the results of the preliminary statistical analysis for TSS. The analysis for each of the other 21 constituents is given in a separate appendix, starting on page 723 , near the end of this volume. A complete table 
is located at: http://www.bama.ua.edu/ maest001/Research/NSQD/

\section{Acknowledgments}

We want to thank all the communities that have submitted their information for inclusion in the NSQD Database. The graduate students at the University of Alabama, specially Sanju Jacob, Summandeep Shergill, Veera Rao Karri, Yukio Nara, Soumya Chaturvedula and Renee Morquecho. Project support and assistance from Bryan Rittenhouse and the EPA Office of Water is appreciated. The employees of the Center of Watershed Protection are thanked for their support and dedication with the database. We appreciate the interest and support of Dr. Chakraborti from the statistics department at the University of Alabama.

\section{References}

Adams B., and Papa F. 2000. Urban Stormwater Management Planning with Analytical Probabilistic Methods. John Wiley and Sons. New York, NY.

Bertrand-Krajewski, J., 1998. Distribution of Pollutant Mass vs Volume in Stormwater Discharges and the First Flush Phenomenon, in Water Resources, Volume 32, No. 8 p. $2341-2356$.

Brown T., Burd W., Lewis J., and Chang G., 1995. Methods and Procedures in Stormwater Data Collection, in Stormwater NPDES Related Monitoring Needs. ASCE. p. 198.

Burton G. A. and Pitt R., 2002. Stormwater Effects Handbook: A Toolbox for Watershed Managers, Scientists and Engineers. CRC press LLC, Boca Raton, FL.

Deletic, A., 1998. The First Flush Load of Urban Surface Runoff, in Water Research, Volume 32, No 8, pp. 2462-2470.

Dickinson J., and Chakraborti S., 1992. Nonparametric Statistical Inference. 3rd edition. Marcel Dekker Inc., New York, NY.

Dodson, R., 1995. Storm Water Pollution Control: Industry \& Construction NPDES Compliance. McGraw-Hill, New York, NY.

Ellis, J.B., 1986. Pollutional aspects of urban runoff, in Urban Runoff Polution. NATO ASI Series Berlin Heidelberg: Springer-Verlag eds., Vol. G10. p 1 - 38.

Fligner M., and Policello, G., 1981. Robust Rank Procedures for the Behrens-Fisher Problem in Journal of the American Statistical Association, Volume 76, Issue 373. p 162-168.

Hollander M., and Wolfe D., 1999. Non Parametric Statistical Methods. Second edition. John Wiley and Sons, Inc, New York, NY. 
Table 15-5 Results of preliminary statistical analysis for TSS.

\begin{tabular}{lccccccccc}
\hline \multicolumn{1}{c}{ TSS (mg/L) } & $\begin{array}{c}\text { Total } \\
\text { Events }\end{array}$ & $\begin{array}{c}\text { Selected } \\
\text { Cases }\end{array}$ & Median & $\begin{array}{c}\text { Median } \\
(\log )\end{array}$ & $\begin{array}{c}\text { Var } \\
(\text { Log })\end{array}$ & $\begin{array}{c}\text { Skew } \\
(\text { Log) }\end{array}$ & $\begin{array}{c}\text { SE } \\
\text { Skew } \\
(\text { Log) }\end{array}$ & $\begin{array}{c}\text { Test } \\
\text { Norm. } \\
\text { (Log) }\end{array}$ & $\begin{array}{c}\text { Median } \\
\text { Ratio }\end{array}$ \\
\hline Commercial Composite & 90 & 90 & 54.95 & 1.740 & 0.106 & 0.168 & 0.254 & 0.730 & 1.85 \\
Commercial First Flush & 90 & 90 & 101.86 & 2.008 & 0.200 & -0.508 & 0.254 & 0.016 & \\
Industrial Composite & 83 & 83 & 66.07 & 1.820 & 0.186 & -0.021 & 0.264 & 0.336 & 0.97 \\
Industrial First Flush & 83 & 83 & 63.97 & 1.806 & 0.374 & -0.157 & 0.264 & 0.055 & \\
Institutional Composite & 18 & 18 & 16.48 & 1.217 & 0.110 & -0.176 & 0.536 & 0.122 & 2.12 \\
Institutional First Flush & 18 & 18 & 34.99 & 1.544 & 0.145 & -0.164 & 0.536 & 0.846 & \\
Open Space Composite & 32 & 32 & 21.98 & 1.342 & 0.424 & -0.526 & 0.414 & 0.511 & 0.95 \\
Open Space First Flush & 32 & 32 & 20.89 & 1.320 & 0.563 & -0.126 & 0.414 & 0.847 & \\
Residential Composite & 144 & 144 & 37.50 & 1.574 & 0.217 & -0.033 & 0.202 & 0.282 & 1.84 \\
Residential First Flush & 144 & 144 & 69.02 & 1.839 & 0.302 & -0.267 & 0.202 & 0.533 & \\
All Landuses Composite & 372 & 372 & 44.36 & 1.647 & 0.226 & -0.381 & 0.126 & 0.008 & 1.60 \\
All Landuses First Flush & 372 & 372 & 70.96 & 1.851 & 0.335 & 0.457 & 0.126 & 0 \\
\hline
\end{tabular}

\begin{tabular}{lccccc}
\hline \multicolumn{1}{c}{ TSS } & $\begin{array}{c}\text { Mann Wittn. p- } \\
\text { value }\end{array}$ & Fligner Policello & $\begin{array}{c}\text { Normality for } \mathrm{t} \text { - } \\
\text { test p-value }\end{array}$ & $\begin{array}{c}\text { Paired } \\
\mathrm{t} \text {-test }\end{array}$ & Result \\
\hline Commercial & $\mathrm{N} / \mathrm{A}$ & $\mathrm{U}=5.345 ; \mathrm{P}=0$ & 0.014 & $\mathrm{~N} / \mathrm{A}$ & Different (first flush) \\
Industrial & 0.627 & $\mathrm{U}=0.483 ; \mathrm{P}=0.31$ & 0.222 & 0.432 & Same (no first flush) \\
Institutional & 0.007 & $\mathrm{U}=3.095 ; \mathrm{P}=0$ & 0.309 & 0.001 & Different \\
Open Space & 0.706 & $\mathrm{U}=0.39 ; \mathrm{P}=0.35$ & 0.183 & 0.614 & Same \\
Residential & $\mathrm{N} / \mathrm{A}$ & $\mathrm{U}=4.89 ; \mathrm{P}=0$ & 0 & N/A & Different \\
All Landuses & $\mathrm{N} / \mathrm{A}$ & $\mathrm{U}=6.65 ; \mathrm{P}=0$ & 0 & N/A & Different \\
\hline
\end{tabular}


Kottegoda N. and Rosso R., 1999. Statistics, Probability, and Reliability for Civil and Environmental Engineers. McGraw Hill, Inc, New York, NY.

Pitt R., Lilburn M., Durrans S.R., Burian S., Nix S., Voorhees J., and Martinson J., 1999. Guidance Manual for Integrated Wet Weather Flow (WWF) Collection and Treatments Systems for Newly Urbanized Areas. U.S. Environmental Protection Agency.

Pitt R., and Voorhees J., 1995. Source Loading and Management Model (SLAMM), in Seminar Publication: National Conference on Urban Runoff Management: Enhancing Urban Watershed Management at the Local, County, and State Levels. U.S. Environmental Protection Agency, EPA/625/R-95/003, Cincinnati, $\mathrm{OH}$.

Pitt, R., Maestre A., and Morquecho R., 2003. Evaluation of NPDES phase I Municipal Stormwater Monitoring Data, in National Conference on Urban Stormwater: Enhancing the Programs at the Local Level. EPA/625/R-03/003.

Roa-Espinosa A., and Bannerman R., 1995. Monitoring BMP effectiveness at Industrial Sites, in Stormwater NPDES Related Monitoring Needs. ASCE. p 467 $-486$.

Smullen, J.T. and Cave K.A., 2002. National stormwater runoff pollution database, in Wet-Weather Flow in the Urban Watershed. Lewis Publishers, Boca Raton. FL. p67-78.

Soeur C., Hubka J., Chang G., 1995. Methods for Assessing Urban Storm Water Pollution, in Stormwater NPDES Related Monitoring Needs. ASCE. p. 558.

Swietlik W., 1995. Strategies for Using NPDES Storm Water Data, in Stormwater NPDES Related Monitoring Needs. ASCE. p. 244

SYSTAT, 1998. Statistics, Version 8.0, (SPSS Inc., Chicago IL., 1086p.)

Tetratech Inc., 2000. NPDES/KPDES Phase I Stormwater Monitoring Data. Lexington-Fayette Urban County Government. Personal communication.

U.S. Environmental Protection Agency. Dec 1983. Results of the Nationwide Runoff Program. Water Planning Division, PB 84-185552, Washington D.C.

WEF, ASCE. Urban Runoff Quality Management. WEF Manual Practice No. 23. ASCE Manual and Report on Engineering Practice No. 87. 1998 


\section{Appendix to Chapter 15, Comprising 22 Tables of Statistical Analysis}

Alex Maestre, Robert Pitt and Derek Williamson 
Table 15-5 cont'd Results of preliminary statistical analysis for Turbidity.

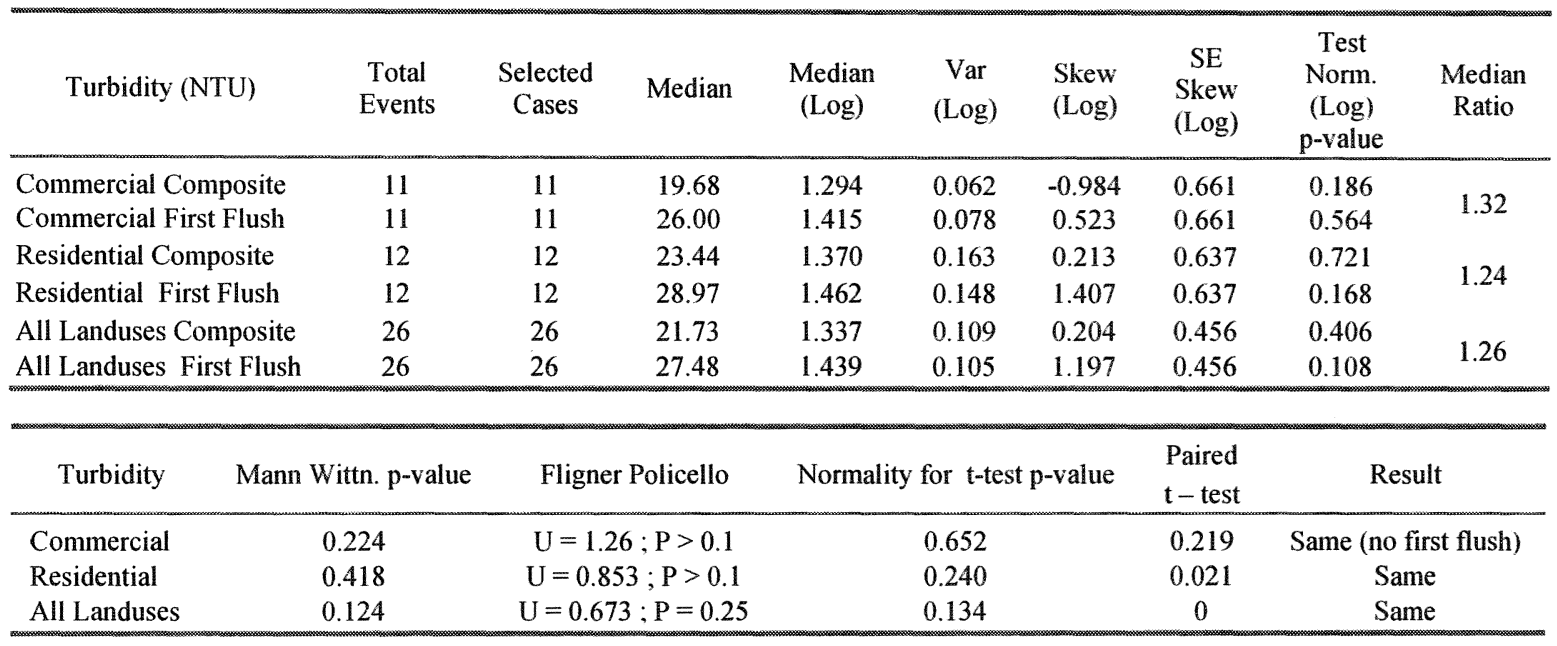


Table 15-5 cont'd Results of preliminary statistical analysis for $\mathrm{pH}$.

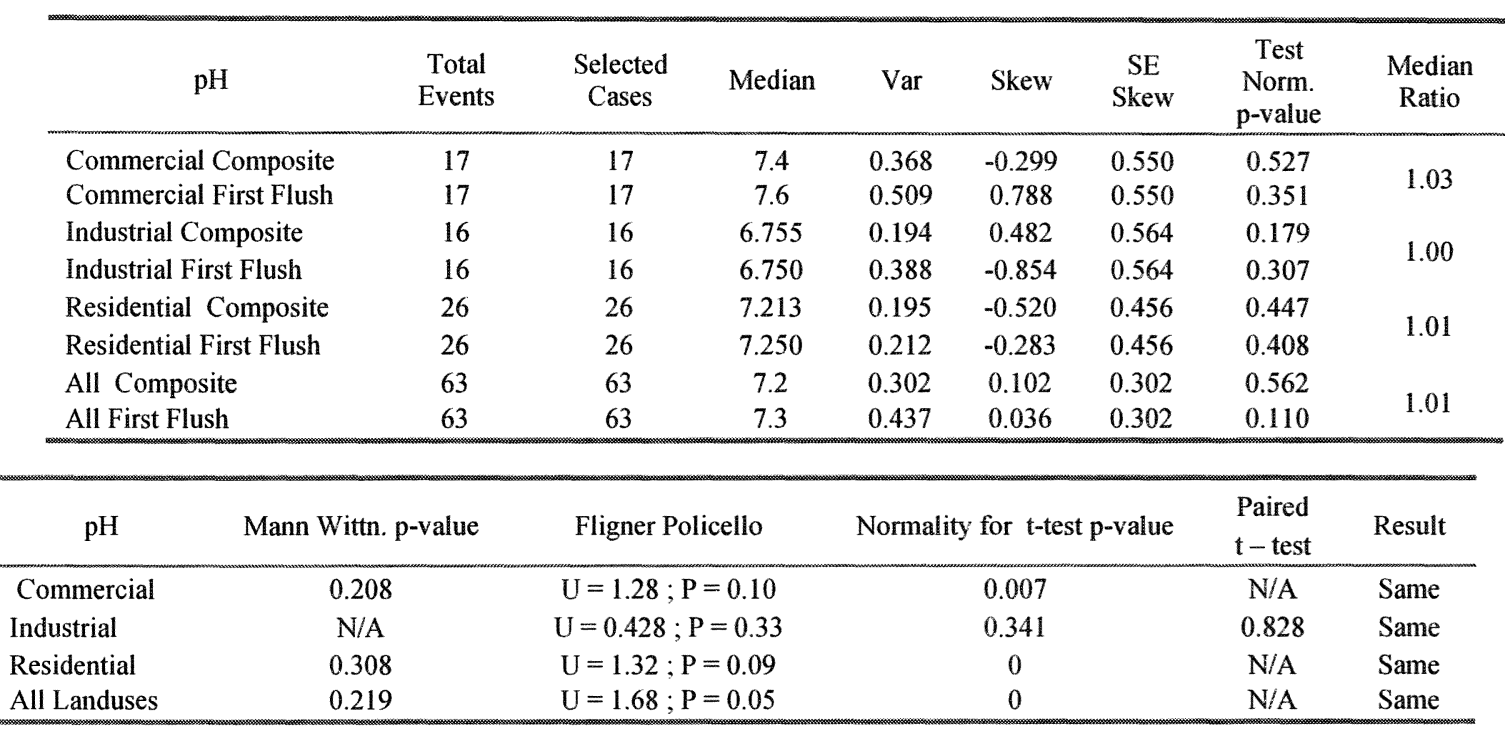


Table 15-5 cont'd Results of preliminary statistical analysis for $\mathrm{BOD}_{5}$.

\begin{tabular}{|c|c|c|c|c|c|c|c|c|c|c|}
\hline \multicolumn{2}{|c|}{$\mathrm{BOD}_{s}(\mathrm{mg} / \mathrm{L})$} & $\begin{array}{l}\text { Total } \\
\text { Events }\end{array}$ & $\begin{array}{l}\text { Selected } \\
\text { Cases }\end{array}$ & Median & $\begin{array}{l}\text { Median } \\
\text { (Log) }\end{array}$ & $\begin{array}{l}\text { Var } \\
\text { (Log) }\end{array}$ & $\begin{array}{l}\text { Skew } \\
\text { (Log) }\end{array}$ & $\begin{array}{c}\text { SE } \\
\text { Skew } \\
\text { (Log) }\end{array}$ & $\begin{array}{c}\text { Test } \\
\text { Norm. } \\
\text { (Log) } \\
\text { p-value }\end{array}$ & $\begin{array}{l}\text { Median } \\
\text { Ratio }\end{array}$ \\
\hline \multirow{2}{*}{\multicolumn{2}{|c|}{$\begin{array}{l}\text { Commercial Composite } \\
\text { Commercial First Flush }\end{array}$}} & 83 & 83 & 15.21 & 1.182 & 0.125 & 0.263 & 0.264 & 0.513 & \multirow{2}{*}{1.77} \\
\hline & & 83 & 83 & 26.98 & 1.431 & 0.153 & -0.241 & 0.264 & 0.390 & \\
\hline \multicolumn{2}{|c|}{ Industrial Composite } & 80 & 80 & 15.14 & 1.18 & 0.188 & 0.190 & 0.269 & 0.013 & \multirow{2}{*}{1.58} \\
\hline \multicolumn{2}{|c|}{ Industrial First Flush } & 80 & 80 & 23.99 & 1.38 & 0.180 & -0.502 & 0.269 & 0.044 & \\
\hline \multirow{2}{*}{\multicolumn{2}{|c|}{$\begin{array}{l}\text { Institutional Composite } \\
\text { Institutional First Flush }\end{array}$}} & 18 & 18 & 7.48 & 0.874 & 0.151 & -0.737 & 0.536 & 0.247 & \multirow{2}{*}{1.67} \\
\hline & & 18 & 18 & 12.47 & 1.096 & 0.173 & -0.732 & 0.536 & 0.281 & \\
\hline \multirow{2}{*}{\multicolumn{2}{|c|}{$\begin{array}{l}\text { Open Space Composite } \\
\text { Open Space First Flush }\end{array}$}} & 28 & 28 & 3.79 & 0.579 & 0.148 & 0.523 & 0.441 & 0.242 & \multirow{2}{*}{1.07} \\
\hline & & 28 & 28 & 4.05 & 0.607 & 0.197 & 0.449 & 0.441 & 0.077 & \\
\hline \multirow{2}{*}{\multicolumn{2}{|c|}{$\begin{array}{l}\text { Residential Composite } \\
\text { Residential First Flush }\end{array}$}} & 133 & 133 & 12.59 & 1.100 & 0.154 & 0.314 & 0.210 & 0.137 & \multirow{2}{*}{1.67} \\
\hline & & 133 & 133 & 20.99 & 1.322 & 0.220 & -0.150 & 0.210 & 0.010 & \\
\hline \multirow{2}{*}{\multicolumn{2}{|c|}{$\begin{array}{l}\text { All Landuses Composite } \\
\text { All Landuses First Flush }\end{array}$}} & 344 & 344 & 12.53 & 1.098 & 0.184 & 0.073 & 0.131 & 0.003 & \multirow{2}{*}{1.67} \\
\hline & & 344 & 344 & 20.89 & 1.320 & 0.233 & -0.385 & 0.131 & 0 & \\
\hline $\mathrm{BOD}_{5}$ & $\begin{array}{l}\text { Mann } \\
\text { Wittn. p- } \\
\text { value } \\
\end{array}$ & \multicolumn{2}{|c|}{ Fligner Policello } & \multicolumn{2}{|c|}{$\begin{array}{l}\text { Normality for } t- \\
\text { test } p-v \text { alue }\end{array}$} & $\begin{array}{l}\text { Paired } \\
t \text {-test }\end{array}$ & \multicolumn{4}{|c|}{ Result } \\
\hline Commercial & 0 & \multirow{2}{*}{\multicolumn{2}{|c|}{$\begin{array}{l}\mathrm{U}=4.85 ; \mathrm{P}=0 \\
\mathrm{U}=2.76 ; \mathrm{P}=0\end{array}$}} & \multicolumn{2}{|c|}{0.013} & $\mathrm{~N} / \mathrm{A}$ & \multicolumn{4}{|c|}{ Different (first flush) } \\
\hline Industrial & 0.007 & & & \multicolumn{2}{|c|}{0.434} & 0.012 & \multicolumn{4}{|c|}{ Different } \\
\hline Institutional & 0.027 & \multicolumn{2}{|c|}{$\mathrm{U}=2.46 ; \mathrm{P}=0.01$} & \multirow{2}{*}{\multicolumn{2}{|c|}{$\begin{array}{l}0.056 \\
0.183\end{array}$}} & 0.001 & \multicolumn{4}{|c|}{ Different } \\
\hline Open Space & 0.706 & \multicolumn{2}{|c|}{$\mathrm{U}=0.39 ; \mathrm{P}=0.35$} & & & 0.614 & & Same (no & irst flush) & \\
\hline Residential & N/A & \multicolumn{2}{|c|}{$\mathrm{U}=4.89 ; \mathrm{P}=0$} & \multicolumn{2}{|c|}{0} & N/A & \multicolumn{4}{|c|}{ Different } \\
\hline All Landuses & N/A & \multicolumn{2}{|c|}{$\mathrm{U}=6.65 ; \mathrm{P}=0$} & \multicolumn{2}{|c|}{0} & N/A & \multicolumn{4}{|c|}{ Different } \\
\hline
\end{tabular}


Table 15-5 cont'd Results of preliminary statistical analysis for COD.

\begin{tabular}{|c|c|c|c|c|c|c|c|c|c|}
\hline $\mathrm{COD}(\mathrm{mg} / \mathrm{L})$ & $\begin{array}{c}\text { Tot } \\
\text { al } \\
\text { Eve } \\
\text { nts }\end{array}$ & $\begin{array}{l}\text { Selected } \\
\text { Cases }\end{array}$ & Median & $\begin{array}{c}\text { Median } \\
(\mathrm{Log})\end{array}$ & $\begin{array}{l}\text { Var } \\
(\log )\end{array}$ & $\begin{array}{l}\text { Skew } \\
(\log )\end{array}$ & $\begin{array}{c}\text { SE } \\
\text { Skew } \\
\text { (Log) }\end{array}$ & $\begin{array}{c}\text { Test } \\
\text { Norm. } \\
\text { (Log) } \\
\text { p-value }\end{array}$ & $\begin{array}{l}\text { Median } \\
\text { Ratio }\end{array}$ \\
\hline Commercial Composite) & 91 & 91 & 71.94 & 1.857 & 0.075 & 0.261 & 0.253 & 0.022 & \multirow{2}{*}{2.29} \\
\hline Commencial First Flush & 91 & 91 & 164.82 & 2.217 & 0.119 & -0.201 & 0.253 & 0.877 & \\
\hline \multirow{2}{*}{$\begin{array}{l}\text { Industrial Composite } \\
\text { Industrial First. Flush }\end{array}$} & 84 & 84 & 75.34 & 1.877 & 0.100 & 0.167 & 0.263 & 0.014 & \multirow{2}{*}{1.43} \\
\hline & 84 & 84 & 107.40 & 2.031 & 0.151 & -0.141 & 0.263 & 0.804 & \\
\hline \multirow{2}{*}{$\begin{array}{l}\text { Institutional Composite } \\
\text { Institutional First Flush }\end{array}$} & 18 & 18 & 43.85 & 1.642 & 0.220 & -0.456 & 0.536 & 0.567 & \multirow{2}{*}{2.73} \\
\hline & 18 & 18 & 119.67 & 2.078 & 0.151 & -0.969 & 0.536 & 0.105 & \\
\hline \multirow{2}{*}{$\begin{array}{l}\text { Open Space Composite } \\
\text { Open Space First Flush }\end{array}$} & 28 & 28 & 20.00 & 1.301 & 0.130 & 0.441 & 0.441 & 0.084 & \multirow{2}{*}{0.67} \\
\hline & 28 & 28 & 13.43 & 1.128 & 0.211 & 0.731 & 0.441 & 0.013 & \\
\hline \multirow{2}{*}{$\begin{array}{l}\text { Residential Composite } \\
\text { Residential First Flush }\end{array}$} & 140 & 140 & 67.92 & 1.832 & 0.095 & 0.271 & 0.205 & 0.008 & \multirow{2}{*}{1.63} \\
\hline & 140 & 140 & 110.41 & 2.043 & 0.138 & -0.831 & 0.205 & 0.005 & \\
\hline \multirow{2}{*}{$\begin{array}{l}\text { All Landuses Composite } \\
\text { All Landuses First Flush }\end{array}$} & 363 & 363 & 65.92 & 1.819 & 0.123 & -0.293 & 0.128 & 0 & \multirow{2}{*}{1.71} \\
\hline & 363 & 363 & 112.98 & 2.053 & 0.194 & -0.710 & 0.128 & 0 & \\
\hline Mar & $\begin{array}{l}\text { Mann Wittn. p- } \\
\text { value }\end{array}$ & \multicolumn{2}{|c|}{ Fligner Policello } & \multicolumn{2}{|c|}{$\begin{array}{l}\text { Normality for } t- \\
\text { test } p-v \text { alue }\end{array}$} & $\begin{array}{l}\text { Paired } \\
\mathrm{t} \text {-test }\end{array}$ & \multicolumn{3}{|c|}{ Result } \\
\hline Commercial & N/A & \multicolumn{2}{|c|}{$\mathrm{U}=4.83 ; \mathrm{P}=0$} & \multicolumn{2}{|c|}{0.269} & 0 & \multicolumn{3}{|c|}{ Different (first flush) } \\
\hline Industrial & N/A & \multicolumn{2}{|c|}{$\mathrm{U}=1.67 ; \mathrm{P}=0.05$} & \multicolumn{2}{|c|}{0.691} & 0.01 & \multicolumn{3}{|c|}{ Different } \\
\hline Institutional & 0.01 & \multicolumn{2}{|c|}{$U=2.94 ; P=0$} & \multicolumn{2}{|c|}{0.677} & 0 & \multicolumn{3}{|c|}{ Different } \\
\hline Open Space & $\mathrm{N} / \mathrm{A}$ & \multicolumn{2}{|c|}{$\mathrm{U}=0.269 ; \mathrm{P}=0.39$} & \multicolumn{2}{|c|}{0.004} & N/A & \multicolumn{3}{|c|}{ Same (no first flush) } \\
\hline Residential & & $\mathrm{U}=6$ & $15 ; P=0$ & & & N/A & & Different & \\
\hline All Landuses & & $\mathrm{U}=$ & $19 ; P=0$ & & & $\mathrm{~N} / \mathrm{A}$ & & Different & \\
\hline
\end{tabular}


Table 15-5 cont'd Results of preliminary statistical analysis for TDS.

\begin{tabular}{lccccccccc}
\hline \multicolumn{1}{c}{ TDS (mg/L) } & $\begin{array}{c}\text { Total } \\
\text { Events }\end{array}$ & $\begin{array}{c}\text { Selected } \\
\text { Cases }\end{array}$ & Median & $\begin{array}{c}\text { Median } \\
\text { (Log) }\end{array}$ & $\begin{array}{c}\text { Var } \\
\text { (Log) }\end{array}$ & $\begin{array}{c}\text { Skew } \\
(\text { Log) }\end{array}$ & $\begin{array}{c}\text { SE } \\
\text { Skew } \\
\text { (Log) }\end{array}$ & $\begin{array}{c}\text { Test } \\
\text { (Log) } \\
\text { p-value }\end{array}$ & $\begin{array}{c}\text { Mediar. } \\
\text { Ratio }\end{array}$ \\
\hline Commercial Composite & 82 & 82 & 73.28 & 1.865 & 0.064 & -0.338 & 0.266 & 0.263 & 1.83 \\
Commercial First Flush & 82 & 82 & 133.97 & 2.127 & 0.065 & -0.219 & 0.266 & 0.115 & \\
Industrial Composite & 82 & 81 & 97.72 & 1.990 & 0.093 & -0.482 & 0.267 & 0.341 & 1.32 \\
Industrial First Flush & 82 & 81 & 128.82 & 2.110 & 0.126 & -0.513 & 0.267 & 0.109 & \\
Institutional Composite & 18 & 18 & 52.48 & 1.720 & 0.068 & -0.034 & 0.536 & 0.360 & 2.66 \\
Institutional First Flush & 18 & 18 & 139.64 & 2.145 & 0.090 & -0.303 & 0.536 & 0.158 & \\
Open Space Composite & 31 & 30 & 69.98 & 1.845 & 0.051 & 0.617 & 0.427 & 0.376 & 1.07 \\
Open Space First Flush & 31 & 30 & 74.99 & 1.875 & 0.104 & -1.483 & 0.427 & 0.005 & \\
Residential Composite & 137 & 133 & 70.31 & 1.870 & 0.119 & -0.245 & 0.210 & 0.041 & 1.52 \\
Residential First Flush & 137 & 133 & 107.15 & 2.030 & 0.125 & 0.500 & 0.210 & 0.167 & \\
All Landuses Composite & 354 & 342 & 77.62 & 1.890 & 0.083 & 0.188 & 0.132 & 0.334 & 1.55 \\
All Landuses First Flush & 354 & 342 & 120.23 & 2.080 & 0.104 & 0.225 & 0.132 & 0.126 & 1.56 \\
\hline
\end{tabular}

\begin{tabular}{lccccc}
\hline \multicolumn{1}{c}{ TDS } & Mann Wittn. p-value & Fligner Policello & $\begin{array}{c}\text { Normality for } \mathrm{t} \text { - } \\
\text { test } \mathrm{p} \text {-value }\end{array}$ & $\begin{array}{c}\text { Paired } \\
\mathrm{t} \text {-test }\end{array}$ & Result \\
\hline Commercial & 0 & $\mathrm{U}=7.33 ; \mathrm{P}=0$ & 0.160 & 0 & Different (first flush) \\
Industrial & 0.0245 & $\mathrm{U}=2.28 ; \mathrm{P}=0.01$ & 0.070 & 0.003 & Different \\
Institutional & 0.0118 & $\mathrm{U}=2.945 ; \mathrm{P}=0$ & 0.544 & 0 & Different \\
Open Space & N/A & $\mathrm{U}=0.161 ; \mathrm{P}=0.44$ & 0 & N/A & Same (no first flush) \\
Residential & N/A & $\mathrm{U}=4.89 ; \mathrm{P}=0$ & 0 & N/A & Different \\
All Landuses & 0 & $\mathrm{U}=7.58 ; \mathrm{P}=0$ & 0 & N/A & Different \\
\hline
\end{tabular}


Table 15-5 cont'd Results of preliminary statistical analysis for O\&G.

\begin{tabular}{|c|c|c|c|c|c|c|c|c|c|}
\hline$O \& G(\mathrm{mg} / \mathrm{L})$ & $\begin{array}{l}\text { Total } \\
\text { Events }\end{array}$ & $\begin{array}{l}\text { Selected } \\
\text { Cases }\end{array}$ & Median & $\begin{array}{c}\text { Median } \\
(\text { Log) }\end{array}$ & $\begin{array}{c}\text { Var } \\
(\log )\end{array}$ & $\begin{array}{l}\text { Skew } \\
\text { (Log) }\end{array}$ & $\begin{array}{c}\text { SE } \\
\text { Skew } \\
(\text { Log) } \\
\end{array}$ & $\begin{array}{l}\text { Test Norm. } \\
\text { (Log) } \\
\text { p-value }\end{array}$ & $\begin{array}{c}\text { Median } \\
\text { Ratio }\end{array}$ \\
\hline Commercial Composite & 10 & 10 & 5.19 & 0.715 & 0.068 & -0.976 & 0.687 & 0.016 & \multirow{2}{*}{1.54} \\
\hline Commercial First Flush & 10 & 10 & 8.00 & 0.027 & 0.903 & 1.641 & 0,687 & 0.019 & \\
\hline Residential Composite & 8 & 4 & 5.00 & 0.699 & 0.066 & 1.985 & 1.014 & 0.013 & \multirow{2}{*}{2.05} \\
\hline Residential First Flush & 8 & 4 & 10.23 & 1.010 & 0.134 & 0.003 & 1.014 & 0.056 & \\
\hline All Landuses Composite & 18 & 14 & 5.00 & 0.699 & 0.073 & -0.370 & 0.597 & 0.015 & \multirow{2}{*}{1.60} \\
\hline All Landuses First Flush & 18 & 14 & 8.00 & 0.903 & 0.051 & 0.890 & 0.597 & 0.011 & \\
\hline$O \& G$ & $\begin{array}{l}\text { Mann Wittn. } \\
\text { p-value }\end{array}$ & & \multicolumn{2}{|c|}{ Fligner Policello } & \multicolumn{2}{|c|}{$\begin{array}{c}\text { Normality for t-test } \\
\text { p-value }\end{array}$} & $\begin{array}{l}\text { Paired } \\
t-\text { test }\end{array}$ & Result & \\
\hline Commercial & N/A & & \multirow{3}{*}{\multicolumn{2}{|c|}{$\begin{array}{c}U=6.198 ; P<0.01 \\
U=1.069 ; P>0.1 \\
U=4.072 ; P=0\end{array}$}} & \multicolumn{2}{|c|}{0.222} & 0.004 & Different & \\
\hline Residential & N/A & & & & \multicolumn{2}{|c|}{0.049} & 0.306 & Same & \\
\hline All Landuses & $\mathrm{N} / \mathrm{A}$ & & & & \multicolumn{2}{|c|}{0.036} & N/A & Different & \\
\hline
\end{tabular}


Table 15-5 cont'd Results of preliminary statistical analysis for Fecal Coliforms.

\begin{tabular}{|c|c|c|c|c|c|c|c|c|c|}
\hline $\begin{array}{l}\text { Fecal Coliforms } \\
(\mathrm{mpn} / 100 \mathrm{~mL})\end{array}$ & $\begin{array}{l}\text { Total } \\
\text { Events }\end{array}$ & $\begin{array}{l}\text { Selected } \\
\text { Cases }\end{array}$ & Median & $\begin{array}{c}\text { Median } \\
(\text { Log })\end{array}$ & $\begin{array}{l}\text { Var } \\
(\log )\end{array}$ & $\begin{array}{l}\text { Skew } \\
\text { (Log) }\end{array}$ & $\begin{array}{c}\text { SE } \\
\text { Skew } \\
\text { (Log) }\end{array}$ & $\begin{array}{c}\text { Test } \\
\text { Norm. } \\
\text { (Log) } \\
\text { p-value }\end{array}$ & $\begin{array}{c}\text { Median } \\
\text { Ratio }\end{array}$ \\
\hline Commercial Composite & 12 & 12 & 67764 & 4.831 & 1.099 & -0.691 & 0.637 & 0.627 & \multirow{2}{*}{0.87} \\
\hline Commercial First Flush & 12 & 12 & 58884 & 4.770 & 1.732 & -0.388 & 0.637 & 0.228 & \\
\hline Residential Composite & 10 & 9 & 41976 & 4.623 & 0.292 & 0.485 & 0.717 & 0.276 & \multirow{2}{*}{0.98} \\
\hline Residential First Flush & 10 & 9 & 41020 & 4.643 & 0.685 & 0.247 & 0.717 & 0.799 & \\
\hline All Landuses Composite & 22 & 21 & 46238 & 4.665 & 0.745 & -0.886 & -0.515 & 0.511 & \multirow[b]{2}{*}{1.21} \\
\hline All Landuses First Flush & 22 & 21 & 55976 & 4.748 & 1.269 & 0.501 & 0.501 & 0.391 & \\
\hline Fecal Coliforms & \multicolumn{2}{|c|}{$\begin{array}{l}\text { Mann Wittn. } \\
\text { p-value }\end{array}$} & \multicolumn{2}{|c|}{ Fligner Policello } & \multicolumn{2}{|c|}{$\begin{array}{l}\text { Normality for } t \text {-test } \\
\text { p-value }\end{array}$} & $\begin{array}{l}\text { Paired } \\
\mathrm{t} \text { - test }\end{array}$ & Result & \\
\hline Commercial & N/A & & \multirow{3}{*}{\multicolumn{2}{|c|}{$\begin{array}{c}\mathrm{U}=0 ; \mathrm{P}>0.10 \\
\mathrm{U}=0.289 ; \mathrm{P}>0.1 \\
\mathrm{U}=0.181 ; \mathrm{P}=0.43\end{array}$}} & \multicolumn{2}{|c|}{0.833} & 0.583 & Same & \\
\hline Residential & N/A & & & & \multicolumn{2}{|c|}{0.016} & 0.973 & Same & \\
\hline All Landuses & N/A & & & & \multicolumn{2}{|c|}{0.086} & 0.665 & Same & \\
\hline
\end{tabular}


Table 15-5 cont'd Results of preliminary statistical analysis for Fecal Streptococcus.

\begin{tabular}{lccccc}
\hline $\begin{array}{c}\text { Fecal } \\
\text { Streptococcus } \\
\text { (mpn/100mL) }\end{array}$ & $\begin{array}{c}\text { Mann Wittn. } \\
\text { p-value }\end{array}$ & Fligner Policello & $\begin{array}{c}\text { Normality for } \\
\text { t-test } \text {-value }\end{array}$ & $\begin{array}{c}\text { Paired } \\
\mathrm{t}-\text { test }\end{array}$ & Result \\
\hline Commercial & N/A & $\mathrm{U}=0.281 ; \mathrm{P}>0.10$ & 0.027 & N/A & Same (no first flush) \\
Residential & N/A & $\mathrm{U}=0.344 ; \mathrm{P}>0.10$ & 0.109 & 0.905 & Same \\
All Landuses & N/A & $\mathrm{U}=0.309 ; \mathrm{P}=0.38$ & 0.033 & N/A & Same \\
\hline
\end{tabular}




\begin{tabular}{lcccccccccc}
\hline \multicolumn{1}{c}{ Ammonia (mg/L) } & $\begin{array}{c}\text { Total } \\
\text { Events }\end{array}$ & $\begin{array}{c}\text { Selected } \\
\text { Cases }\end{array}$ & Median & $\begin{array}{c}\text { Median } \\
\text { (Log) }\end{array}$ & $\begin{array}{c}\text { Var } \\
\text { (Log) }\end{array}$ & $\begin{array}{c}\text { Skew } \\
\text { (Log) }\end{array}$ & $\begin{array}{c}\text { SE } \\
\text { Skew } \\
\text { (Log) }\end{array}$ & $\begin{array}{c}\text { Test } \\
\text { Norm. } \\
\text { (Log) }\end{array}$ & $\begin{array}{c}\text { Median } \\
\text { Ratio }\end{array}$ \\
\hline Commercial Composite & 70 & 52 & 0.76 & -0.122 & 0.147 & -0.245 & 0.330 & 0.237 & 2.11 \\
Commercial First Flush & 70 & 52 & 1.60 & 0.204 & 0.117 & -0.718 & 0.330 & 0.027 & \\
Industrial Composite & 40 & 33 & 0.62 & -0.208 & 0.166 & -0.399 & 0.409 & 0.284 & 1.08 \\
Industrial First Flush & 40 & 33 & 0.67 & -0.174 & 0.201 & -0.535 & 0.409 & 0.046 & \\
Institutional Composite & 18 & 16 & 0.31 & -0.509 & 0.058 & -0.038 & 0.564 & 0.273 & 1.66 \\
Institutional First Flush & 18 & 16 & 0.51 & -0.290 & 0.077 & 0.284 & 0.564 & 0.384 & \\
Residential Composite & 119 & 86 & 0.50 & -0.301 & 0.370 & 0.779 & 0.260 & 0.001 & 1.36 \\
Residential First Flush & 119 & 86 & 0.68 & -0.168 & 0.172 & 0.195 & 0.260 & 0.519 & \\
All Landuses Composite & 269 & 190 & 0.52 & -0.284 & 0.251 & 0.501 & 0.176 & 0.002 & 1.54 \\
All Landuses First Flush & 269 & 190 & 0.80 & -0.097 & 0.176 & -0.197 & 0.176 & 0.713 & \\
\hline
\end{tabular}

* Ammonia in Open Space was found in 22 ev ents. Only 3 events had values above the detection limit

\begin{tabular}{lccccc}
\hline \multicolumn{1}{c}{ Ammonia } & Mann Wittn. p-yalue & Fligner Policello & Normality for t-test $\mathrm{p}$-value & $\begin{array}{c}\text { Paired } \\
t-\text { test }\end{array}$ & Result \\
\hline Commercial & N/A & $\mathrm{U}=4.467 ; \mathrm{P}=0$ & 0.028 & N/A & Different \\
Industrial & N/A & $\mathrm{U}=0.113 ; \mathrm{P}=0.46$ & 0.262 & 0.985 & Same \\
Institutional & 0.0287 & $\mathrm{U}=2.484 ; \mathrm{P}=0.01$ & 0.254 & 0 & Different \\
Residential & N/A & $\mathrm{U}=2.283 ; \mathrm{P}=0.01$ & 0 & N/A & Different \\
All Landuses & N/A & $\mathrm{U}=4.092 ; \mathrm{P}=0$ & 0 & N/A & Different \\
\hline
\end{tabular}


Table 15-5 cont'd Results of preliminary statistical analysis for $\mathrm{NO}_{2}+\mathrm{NO}_{3}$.

\begin{tabular}{lccccccccc}
\hline \multicolumn{1}{c}{$\mathrm{NO}_{2}+\mathrm{NO}_{3}$ (mg/L) } & $\begin{array}{c}\text { Total } \\
\text { Events }\end{array}$ & $\begin{array}{c}\text { Selected } \\
\text { Cases }\end{array}$ & Median & $\begin{array}{c}\text { Median } \\
(\mathrm{Log})\end{array}$ & $\begin{array}{c}\text { Var } \\
(\mathrm{Log})\end{array}$ & $\begin{array}{c}\text { Skew } \\
(\mathrm{L} \text { og })\end{array}$ & $\begin{array}{c}\text { SE } \\
\text { Skew } \\
(\mathrm{Log})\end{array}$ & $\begin{array}{c}\text { Test } \\
\text { Norm. } \\
(\mathrm{Log}) \\
\text { p-value }\end{array}$ & $\begin{array}{c}\text { Median } \\
\text { Ratio }\end{array}$ \\
\hline Commercial Composite & 84 & 82 & 0.75 & -0.125 & 0.095 & -0.092 & 0.266 & 0.188 & 1.73 \\
Commercial First Flush & 84 & 82 & 1.30 & 0.114 & 0.166 & -0.790 & 0.266 & 0.007 & \\
Industrial Composite & 72 & 71 & 0.90 & -0.046 & 0.073 & -0.240 & 0.285 & 0.807 & 1.31 \\
Industrial First Flush & 72 & 71 & 1.18 & 0.072 & 0.116 & -0.839 & 0.285 & 0.030 & \\
Institutional & 18 & 18 & 0.60 & -0.222 & 0.122 & -0.714 & 0.536 & 0.117 & 1.70 \\
Institutional First Flush & 18 & 18 & 1.02 & 0.009 & 0.151 & 0.268 & 0.536 & 0.381 & \\
Open Space Composite & 30 & 21 & 0.24 & -0.620 & 0.290 & 0.468 & 0.501 & 0.141 & 0.96 \\
Open Space First Flush & 30 & 21 & 0.23 & -0.638 & 0.356 & 0.823 & 0.501 & 0.030 & \\
Residential Composite & 121 & 118 & 0.60 & -0.222 & 0.104 & -0.196 & 0.223 & 0.504 & 1.66 \\
Residential First Flush & 121 & 118 & 1.00 & -0.002 & 0.125 & -0.292 & 0.223 & 0.102 & \\
All Landuses Composite & 324 & 310 & 0.70 & -0.155 & 0.124 & -0.497 & 0.138 & 0 & 1.50 \\
All Landuses First Flush & 324 & 310 & 1.05 & 0.021 & 0.162 & -0.584 & 0.138 & 0 & 0 \\
\hline
\end{tabular}

\begin{tabular}{lccccc}
\hline $\mathrm{NO}_{2}+\mathrm{NO}_{3}$ & Mann Wittn. p-value & Fligner Policello & $\begin{array}{c}\text { Normality for } \mathrm{t} \text {-test } \\
\mathrm{p} \text {-value }\end{array}$ & $\begin{array}{c}\text { Paired } \\
\mathrm{t} \text {-test }\end{array}$ & Result \\
\hline Commercial & $\mathrm{N} / \mathrm{A}$ & $\mathrm{U}=3.286 ; \mathrm{P}=0$ & 0 & N/A & Different (first flush) \\
Industrial & $\mathrm{N} / \mathrm{A}$ & $\mathrm{U}=1.836 ; \mathrm{P}=0.03$ & 0.941 & 0.034 & Different \\
Institutional & 0.043 & $\mathrm{U}=2.242 ; \mathrm{P}=0.01$ & 0.026 & $\mathrm{~N} / \mathrm{A}$ & Different \\
Open Space & $\mathrm{N} / \mathrm{A}$ & $\mathrm{U}=0.209 ; \mathrm{P}=0.42$ & 0.023 & N/A & Same (no first flush) \\
Residential & 0 & $\mathrm{U}=4.769 ; \mathrm{P}=0$ & 0.023 & N/A & Different \\
All Landuses & $\mathrm{N} / \mathrm{A}$ & $\mathrm{U}=5.834 ; \mathrm{P}=0$ & 0 & N/A & Different \\
\hline
\end{tabular}


Table 15-5 cont'd Results of preliminary statistical analysis for Total N.

\begin{tabular}{|c|c|c|c|c|c|c|c|c|c|}
\hline Total N (mg/L) & $\begin{array}{l}\text { Total } \\
\text { Ev ents }\end{array}$ & $\begin{array}{c}\text { Selected } \\
\text { Cases }\end{array}$ & Median & $\begin{array}{l}\text { Median } \\
(\log )\end{array}$ & $\begin{array}{l}\text { Var } \\
(\mathrm{L} o g)\end{array}$ & $\begin{array}{l}\text { Skew } \\
\text { (Log) }\end{array}$ & $\begin{array}{c}\text { SE } \\
\text { Skew } \\
\text { (Log) }\end{array}$ & $\begin{array}{c}\text { Test } \\
\text { Norm. } \\
\text { (Log) } \\
\text { p-value }\end{array}$ & $\begin{array}{c}\text { Median } \\
\text { Ratio }\end{array}$ \\
\hline Commercial Composite & 19 & 19 & 1.42 & 0.152 & 0.180 & -0.133 & 0.524 & 0.215 & \multirow{2}{*}{1.35} \\
\hline Commercial First Flush & 19 & 19 & 1.91 & 0.281 & 0.203 & -0.617 & 0.524 & 0.337 & \\
\hline Industrial Composite & 19 & 16 & 2.01 & 0.303 & 0.286 & -0.306 & 0.564 & 0.431 & \multirow{2}{*}{1.79} \\
\hline Industrial First Flush & 19 & 16 & 3.61 & 0.557 & 0.349 & -0.452 & 0.564 & 0.029 & \\
\hline Open Space Composite & 6 & 6 & 1.39 & 0.142 & 0.112 & -0.150 & 0.845 & 0.330 & \multirow{2}{*}{1.53} \\
\hline Open Space First Flush & 6 & 6 & 2.12 & 0.326 & 0.248 & -0.100 & 0.845 & 0.221 & \\
\hline Residential Composite & 31 & 30 & 1.67 & 0.222 & 0.325 & 1.22 & 0.427 & 0.009 & \multirow{2}{*}{0.88} \\
\hline Residential First Flush & 31 & 30 & 1.47 & 0.166 & 0.447 & -0.587 & 0.427 & 0.367 & \\
\hline All Landuses Composite & 77 & 73 & 1.60 & 0.204 & 0.253 & 0.769 & 0.281 & 0.136 & \multirow{2}{*}{1.22} \\
\hline All Landuses First Flush & 77 & 73 & 1.95 & 0.290 & 0.331 & 0.599 & 0.281 & 0.071 & \\
\hline
\end{tabular}

\begin{tabular}{lccccc}
\hline Constituent & Mann Wittn. p-value & Fligner Policello & Normality for t-test p-value & $\begin{array}{c}\text { Paired } \\
t \text {-test }\end{array}$ & Result \\
\hline Commercial & 0.220 & $\mathrm{U}=1.234 ; \mathrm{P}=0.11$ & 0.329 & 0.013 & Same \\
Industrial & N/A & $\mathrm{U}=0.460 ; \mathrm{P}=0.32$ & 0.759 & 0.161 & Same \\
Open Space & N/A & $\mathrm{U}=0 ; \mathrm{P}>0.104$ & 0.339 & 0.703 & Same \\
Residential & N/A & $\mathrm{U}=0.106 ; \mathrm{P}=0.46$ & 0.002 & N/A & Same \\
All Landuses & N/A & $\mathrm{U}=0.919 ; \mathrm{P}=0.18$ & 0 & N/A & Same \\
\hline
\end{tabular}


Table 15-5 cont'd Results of preliminary statistical analysis for TKN.

\begin{tabular}{|c|c|c|c|c|c|c|c|c|c|}
\hline TKN (mg/L) & $\begin{array}{l}\text { Total } \\
\text { Events }\end{array}$ & $\begin{array}{l}\text { Selected } \\
\text { Cases }\end{array}$ & Median & $\begin{array}{l}\text { Median } \\
\text { (Log) }\end{array}$ & $\begin{array}{l}\text { Var } \\
(\log )\end{array}$ & $\begin{array}{l}\text { Skew } \\
\text { (Log) }\end{array}$ & $\begin{array}{c}\text { SE } \\
\text { Skew } \\
\text { (Log) } \\
\end{array}$ & $\begin{array}{c}\text { Test } \\
\text { Norm. } \\
\text { (Log) } \\
\text { p-value }\end{array}$ & $\begin{array}{c}\text { Median } \\
\text { Ratio }\end{array}$ \\
\hline Commercial Composite & 93 & 86 & 1.63 & 0.213 & 0.085 & -0.275 & 0.260 & 0.003 & \multirow{2}{*}{1.71} \\
\hline Commercial First Flush & 93 & 86 & 2.80 & 0.447 & 0.120 & -0.117 & 0.260 & 0.714 & \\
\hline Industrial Composite & 77 & 76 & 1.69 & 0.227 & 0.116 & 1.157 & 0.276 & 0 & \multirow{2}{*}{1.35} \\
\hline Industrial First Flush & 77 & 76 & 2.27 & 0.356 & 0.130 & 0.536 & 0.276 & 0.232 & \\
\hline Open Space Composite & 32 & 14 & 0.61 & -0.215 & 0.142 & 0.585 & 0.597 & 0.109 & \multirow{2}{*}{1.28} \\
\hline Open Space First Flush & 32 & 14 & 0.78 & -0.107 & 0.269 & 0.948 & 0.597 & 0.139 & \\
\hline Residential Composite & 131 & 123 & 1.40 & 0.146 & 0.110 & 1.752 & 0.218 & 0 & \multirow{2}{*}{1.65} \\
\hline Residential First Flush & 131 & 123 & 2.31 & 0.364 & 0.115 & 0.309 & 0.218 & 0.076 & \\
\hline All Landuses Composite & 335 & 301 & 1.50 & 0.176 & 0.114 & 0.856 & 0.140 & 0 & \multirow{2}{*}{1.60} \\
\hline All Landuses First Flush & 335 & 301 & 2.40 & 0.380 & 0.139 & 0.088 & 0.140 & 0 & \\
\hline Mann & Nittn. p-value & \multicolumn{2}{|c|}{ Fligner Policello } & \multicolumn{3}{|c|}{$\begin{array}{l}\text { Normality for } t \text {-test p- } \\
\text { value }\end{array}$} & $\begin{array}{l}\text { Paired } \\
t-\text { test }\end{array}$ & \multicolumn{2}{|c|}{ Result } \\
\hline Commercial & $\mathrm{N} / \mathrm{A}$ & \multicolumn{2}{|c|}{$\mathrm{U}=6.499 ; \mathrm{P}=0$} & \multicolumn{3}{|c|}{0.126} & 0 & \multicolumn{2}{|c|}{ Different (first flush) } \\
\hline Industrial & N/A & \multirow{2}{*}{\multicolumn{2}{|c|}{$\begin{array}{l}U=1.698 ; P=0.04 \\
U=0.374 ; P=0.35\end{array}$}} & \multicolumn{3}{|c|}{0.054} & 0.063 & \multicolumn{2}{|c|}{ Different } \\
\hline Open Space & $\mathrm{N} / \mathrm{A}$ & & & & 0.116 & & 0.364 & \multicolumn{2}{|c|}{ Same (no first flush) } \\
\hline Residential & N/A & \multicolumn{2}{|c|}{$\mathrm{U}=6.079 ; \mathrm{P}=0$} & & 0 & & N/A & \multicolumn{2}{|c|}{ Different } \\
\hline All Landuses & $\mathrm{N} / \mathrm{A}$ & \multicolumn{2}{|c|}{$\mathrm{U}=7.68: \mathrm{P}=0$} & & 0 & & $\mathrm{~N} / \mathrm{A}$ & \multicolumn{2}{|c|}{ Different } \\
\hline
\end{tabular}


Table 15-5 cont'd Results of preliminary statistical analysis for Total P.

\begin{tabular}{lccccccccc}
\hline \multicolumn{1}{c}{ Total P (mg/L) } & $\begin{array}{c}\text { Total } \\
\text { Events }\end{array}$ & $\begin{array}{c}\text { Selected } \\
\text { Cases }\end{array}$ & Median & $\begin{array}{c}\text { Median } \\
(\mathrm{Log})\end{array}$ & $\begin{array}{c}\text { Var } \\
(\mathrm{Log})\end{array}$ & $\begin{array}{c}\text { Skew } \\
(\mathrm{Log})\end{array}$ & $\begin{array}{c}\text { SE } \\
\text { Skew } \\
(\mathrm{Log})\end{array}$ & $\begin{array}{c}\text { Test } \\
\text { (Lorm. } \\
\text { p-value }\end{array}$ & $\begin{array}{c}\text { Median } \\
\text { Ratio }\end{array}$ \\
\hline Commercial Composite & 89 & 77 & 0.34 & -0.469 & 0.160 & -0.454 & 0.274 & 0.129 & 1.44 \\
Commercial First Flush & 89 & 77 & 0.49 & -0.310 & 0.205 & 0.033 & 0.274 & 0.035 & \\
Industrial Composite & 84 & 71 & 0.29 & -0.538 & 0.130 & 0.495 & 0.285 & 0.003 & 1.42 \\
Industrial First Flush & 84 & 71 & 0.41 & -0.387 & 0.257 & -0.441 & 0.285 & 0.397 & \\
Institutional Composite & 17 & 17 & 0.17 & -0.770 & 0.203 & -0.736 & 0.550 & 0.374 & 1.24 \\
Institutional First Flush & 17 & 17 & 0.21 & -0.678 & 0.066 & -0.177 & 0.550 & 0.704 & \\
Open Space Composite & 32 & 20 & 0.09 & -1.023 & 0.147 & 0.613 & 0.512 & 0.218 & 1.05 \\
Open Space First Flush & 32 & 20 & 0.10 & -1.000 & 0.381 & 0.833 & 0.512 & 0.288 & \\
Residential Composite & 140 & 128 & 0.28 & -0.553 & 0.252 & 1.232 & 0.214 & 0 & 1.46 \\
Residential First Flush & 140 & 128 & 0.41 & -0.389 & 0.188 & -0.335 & 0.214 & 0.042 & \\
All Landuses Composite & 363 & 313 & 0.28 & -0.553 & 0.209 & 0.605 & 0.138 & 0 & 1.45 \\
All Landuses First Flush & 363 & 313 & 0.41 & -0.391 & 0.238 & -0.258 & 0.138 & 0.003 \\
\hline
\end{tabular}

\begin{tabular}{lccccc}
\hline \multicolumn{1}{c}{ Total P } & $\begin{array}{c}\text { Mann Wittn. } \mathrm{p} \text { - } \\
\text { value }\end{array}$ & Fligner Policello & $\begin{array}{c}\text { Normality for } \mathrm{t} \text { - } \\
\text { test } \mathrm{p} \text {-value }\end{array}$ & $\begin{array}{c}\text { Paired } \\
\mathrm{t} \text {-test }\end{array}$ & Result \\
\hline Commercial & N/A & $\mathrm{U}=3.089 ; \mathrm{P}=0$ & 0.594 & 0 & Different (first flush) \\
Industrial & N/A & $\mathrm{U}=0.864 ; \mathrm{P}=0.19$ & 0.194 & 0.667 & Same (no first flush) \\
Institutional & N/A & $\mathrm{U}=0.774 ; \mathrm{P}=0.22$ & 0.044 & $\mathrm{~N} / \mathrm{A}$ & Same \\
Open Space & N/A & $\mathrm{U}=0.142 ; \mathrm{P}=0.44$ & 0.091 & 0.527 & Same \\
Residential & N/A & $\mathrm{U}=2.671 ; \mathrm{P}=0$ & 0 & N/A & Different \\
All Landuses & N/A & $\mathrm{U}=3.641 ; \mathrm{P}=0$ & 0 & N/A & Different \\
\hline
\end{tabular}


Table 15-5 cont'd Results of preliminary statistical analysis for Dissolved P.

\begin{tabular}{lccccccccc}
\hline \multicolumn{1}{c}{ Dissolved P(mg/L) } & $\begin{array}{c}\text { Total } \\
\text { Events }\end{array}$ & $\begin{array}{c}\text { Selected } \\
\text { Cases }\end{array}$ & Median & $\begin{array}{c}\text { Median } \\
(\mathrm{Log})\end{array}$ & $\begin{array}{c}\text { Var } \\
(\mathrm{Log})\end{array}$ & $\begin{array}{c}\text { Skew } \\
(\mathrm{Log})\end{array}$ & $\begin{array}{c}\text { SE } \\
\text { Skew } \\
(\mathrm{Log})\end{array}$ & $\begin{array}{c}\text { Test } \\
\text { (Log } \\
\text { p-value }\end{array}$ & $\begin{array}{c}\text { Median } \\
\text { Ratio }\end{array}$ \\
\hline Commercial Composite & 91 & 69 & 0.16 & -0.788 & 0.152 & 0.467 & 0.289 & 0 & 1.23 \\
Commercial First Flush & 91 & 69 & 0.20 & -0.699 & 0.212 & 0.904 & 0.289 & 0.005 & \\
Industrial Composite & 77 & 50 & 0.14 & -0.854 & 0.142 & 1.248 & 0.337 & 0.093 & 1.04 \\
Industrial First Flush & 77 & 50 & 0.14 & -0.839 & 0.160 & 0.406 & 0.337 & 0.043 & \\
Institutional Composite & 18 & 14 & 0.13 & -0.891 & 0.066 & -0.114 & 0.597 & 0.563 & 1.05 \\
Institutional First Flush & 18 & 14 & 0.13 & -0.870 & 0.095 & -0.770 & 0.597 & 0.122 & \\
Open Space Composite & 32 & 14 & 0.05 & -1.301 & 0.111 & -0.073 & 0.597 & 0.601 & 0.69 \\
Open Space First Flush & 32 & 14 & 0.03 & -1.460 & 0.087 & 1.061 & 0.597 & 0.017 & \\
Residential Composite & 130 & 105 & 0.17 & -0.770 & 0.117 & 0.152 & 0.236 & 0.458 & 1.24 \\
Residential First Flush & 130 & 105 & 0.21 & -0.678 & 0.170 & 0.121 & 0.236 & 0.044 & \\
All Landuses Composite & 350 & 254 & 0.15 & -0.824 & 0.143 & 0.353 & 0.153 & 0.051 & 1.07 \\
All Landuses First Flush & 350 & 254 & 0.16 & -0.796 & 0.200 & 0.401 & 0.153 & 0.001 \\
\hline
\end{tabular}

\begin{tabular}{lccccc}
\hline \multicolumn{1}{c}{ Dissolved P } & Mann Wittn. p-value & Fligner Policello & $\begin{array}{c}\text { Normality for t-test } \mathrm{p} \text { - } \\
\text { value }\end{array}$ & $\begin{array}{c}\text { Paired } \\
\text { t-test }\end{array}$ & Result \\
\hline Commercial & N/A & $\mathrm{U}=1.582 ; \mathrm{P}=0.06$ & 0.046 & N/A & Same \\
Industrial & N/A & $\mathrm{U}=0.051 ; \mathrm{P}=0.48$ & 0.063 & 0.881 & Same \\
Institutional & 0.549 & $\mathrm{U}=0.605 ; \mathrm{P}=0.27$ & 0.015 & N/A & Same \\
Open Space & N/A & $\mathrm{U}=0.760 ; \mathrm{P}=0.22$ & 0.018 & N/A & Same \\
Residential & N/A & $\mathrm{U}=1.702 ; \mathrm{P}=0.04$ & 0.039 & N/A & Different \\
All Landuses & N/A & $\mathrm{U}=1.657 ; \mathrm{P}=0.05$ & 0 & N/A & Same \\
\hline
\end{tabular}


Table 15-5 cont'd Results of preliminary statistical analysis for Orthophosphate.

\begin{tabular}{lccccccccc}
\hline \multicolumn{1}{c}{ Orthophosphate (mg/L) } & $\begin{array}{c}\text { Total } \\
\text { Events }\end{array}$ & $\begin{array}{c}\text { Selected } \\
\text { Cases }\end{array}$ & Median & $\begin{array}{c}\text { Median } \\
\text { (Log) }\end{array}$ & $\begin{array}{c}\text { Var } \\
(\text { Log) }\end{array}$ & $\begin{array}{c}\text { Skew } \\
(\text { Log) }\end{array}$ & $\begin{array}{c}\text { SE } \\
\text { Skew } \\
\text { (Log) }\end{array}$ & $\begin{array}{c}\text { Test } \\
\text { Norm. } \\
\text { (Log) } \\
\text { p-value }\end{array}$ & $\begin{array}{c}\text { Median } \\
\text { Ratio }\end{array}$ \\
\hline Industrial Composite & 6 & 6 & 0.16 & -0.797 & 0.287 & -0.047 & 0.845 & 0.838 & 1.55 \\
Industrial First Flush & 6 & 6 & 0.25 & -0.607 & 0.356 & -0.106 & 0.845 & 0.720 & \\
Residential Composite & 14 & 14 & 0.19 & -0.714 & 0.554 & 2.557 & 0.597 & 0.001 & 0.95 \\
Residential First Flush & 14 & 14 & 0.18 & -0.737 & 0.214 & 0.708 & 0.597 & 0.362 & \\
All Landuses Composite & 22 & 22 & 0.19 & -0.714 & 0.423 & 2.270 & 0.491 & 0.004 & 1.30 \\
All Landuses First Flush & 22 & 22 & 0.25 & -0.600 & 0.222 & 0.260 & 0.491 & 0.503 & \\
\hline
\end{tabular}

\begin{tabular}{lccccc}
\hline Orthophosphate & Mann Wittn. p-value & Fligner Policello & Normality for t-test p-value & $\begin{array}{c}\text { Paired } \\
\mathrm{t} \text {-test }\end{array}$ & Result \\
\hline Industrial & 0.471 & $\mathrm{U}=0.772 ; \mathrm{P}>0.104$ & 0.071 & 0.611 & Same \\
Residential & N/A & $\mathrm{U}=0.022 ; \mathrm{P}=0.49$ & 0 & N/A & Same \\
All Landuses & N/A & $\mathrm{U}=0.460 ; \mathrm{P}=0.32$ & 0 & N/A & Same \\
\hline
\end{tabular}


Table 15-5 cont'd Results of preliminary statistical analysis for Total Cadmium.

\begin{tabular}{lccccccccc}
\hline Total Cadmium $(\mu \mathrm{g} / \mathrm{L})$ & $\begin{array}{c}\text { Total } \\
\text { Events }\end{array}$ & $\begin{array}{c}\text { Selected } \\
\text { Cases }\end{array}$ & Median & $\begin{array}{c}\text { Median } \\
(\mathrm{Log})\end{array}$ & $\begin{array}{c}\text { Var } \\
(\mathrm{Log})\end{array}$ & $\begin{array}{c}\text { Skew } \\
(\text { Log) }\end{array}$ & $\begin{array}{c}\text { SE } \\
\text { Skew } \\
(\mathrm{Log})\end{array}$ & $\begin{array}{c}\text { Test } \\
\text { Norm. } \\
(\text { Log) } \\
\text { p-value }\end{array}$ & $\begin{array}{c}\text { Median } \\
\text { Ratio }\end{array}$ \\
\hline Commercial Composite & 74 & 48 & 0.56 & -0.253 & 0.246 & -0.325 & 0.343 & 0 & 2.15 \\
Commercial First Flush & 74 & 48 & 1.20 & 0.079 & 0.261 & 0.080 & 0.343 & 0.089 & \\
Industrial Composite & 80 & 41 & 1 & 0 & 0.124 & -0.015 & 0.369 & 0.008 & 1.00 \\
Industrial First Flush & 80 & 41 & 1 & 0 & 0.130 & 0.261 & 0.369 & 0.065 & \\
Open Space Composite & 30 & 15 & 0.23 & -0.638 & 0.282 & 1.074 & 0.580 & 0.183 & 1.30 \\
Open Space First Flush & 30 & 15 & 0.30 & -0.523 & 0.325 & 0.465 & 0.580 & 0.402 & \\
Residential Composite & 123 & 33 & 0.28 & -0.553 & 0.359 & 0.693 & 0.409 & 0.002 & 2.00 \\
Residential First Flush & 123 & 33 & 0.56 & -0.252 & 0.264 & 0.512 & 0.409 & 0.061 & \\
All Landuses Composite & 325 & 139 & 0.60 & -0.222 & 0.269 & -0.065 & 0.206 & 0.071 & 1.62 \\
All Landuses First Flush & 325 & 139 & 0.97 & -0.013 & 0.249 & 0.041 & 0.206 & 0.241 & \\
\hline
\end{tabular}

\begin{tabular}{lccccc}
\hline Total Cadmium & $\begin{array}{c}\text { Mann Wittn. p- } \\
\text { value }\end{array}$ & Fligner Policello & $\begin{array}{c}\text { Normality for } \mathrm{t}- \\
\text { test } \mathrm{p} \text {-value }\end{array}$ & $\begin{array}{c}\text { Paired } \\
\mathrm{t} \text {-test }\end{array}$ & Result \\
\hline Commercial & 0.006 & $\mathrm{U}=2.797 ; \mathrm{P}=0$ & 0.009 & N/A & Different (first flush) \\
Industrial & 0.922 & $\mathrm{U}=0.100 ; \mathrm{P}=0.46$ & 0.118 & 0.529 & Same (no first flush) \\
Open Space & 0.442 & $\mathrm{U}=0.765 ; \mathrm{P}=0.22$ & 0.292 & 0.191 & Same \\
Residential & 0.038 & $\mathrm{U}=2.131 ; \mathrm{P}=0.02$ & 0.015 & N/A & Different \\
All Landuses & 0.005 & $\mathrm{U}=2.839 ; \mathrm{P}=0$ & 0 & N/A & Different \\
\hline
\end{tabular}




\begin{tabular}{lccccccccc}
\hline Total Chromium $(\mu \mathrm{g} / \mathrm{L})$ & $\begin{array}{c}\text { Total } \\
\text { Events }\end{array}$ & $\begin{array}{c}\text { Selected } \\
\text { Cases }\end{array}$ & Median & $\begin{array}{c}\text { Median } \\
(\mathrm{Log})\end{array}$ & $\begin{array}{c}\text { Var } \\
(\mathrm{Log})\end{array}$ & $\begin{array}{c}\text { Skew } \\
(\mathrm{Log})\end{array}$ & $\begin{array}{c}\text { SE } \\
\text { Skew } \\
(\mathrm{Log})\end{array}$ & $\begin{array}{c}\text { Test } \\
\text { Norm. } \\
(\mathrm{Log}) \\
\mathrm{p} \text {-value }\end{array}$ & $\begin{array}{c}\text { Median } \\
\text { Ratio }\end{array}$ \\
\hline Commercial Composite & 47 & 22 & 6.81 & 0.833 & 0.086 & -0.051 & 0.491 & 0.911 & 1.67 \\
Commercial First Flush & 47 & 22 & 11.40 & 1.057 & 0.134 & -0.796 & 0.491 & 0.121 & \\
Industrial Composite & 54 & 25 & 8.79 & 0.944 & 0.111 & 0.338 & 0.464 & 0.456 & 1.36 \\
Industrial First Flush & 54 & 25 & 11.99 & 1.079 & 0.155 & -0.307 & 0.464 & 0.784 & \\
Open Space Composite & 16 & 4 & 2.64 & 0.422 & 0.169 & -0.556 & 1.014 & 0.492 & 1.70 \\
Open Space First Flush & 16 & 4 & 4.50 & 0.653 & 0.015 & 1.291 & 1.014 & 0.355 & \\
Residential Composite & 86 & 31 & 8.00 & 0.903 & 0.169 & -0.077 & 0.421 & 0.612 & 1.24 \\
Residential First Flush & 86 & 31 & 9.91 & 0.996 & 0.137 & 0.326 & 0.421 & 0.904 & \\
All Landuses Composite & 218 & 82 & 7.50 & 0.875 & 0.140 & -0.104 & 0.266 & 0.591 & 1.47 \\
All Landuses First Flush & 218 & 82 & 10.99 & 1.041 & 0.141 & -0.056 & 0.266 & 0.803 \\
\hline
\end{tabular}


Table 15-5 cont'd Results of preliminary statistical analysis for Total Copper.

\begin{tabular}{lccccccccc}
\hline \multicolumn{1}{c}{ Total Copper $(\mu \mathrm{g} / \mathrm{L})$} & $\begin{array}{c}\text { Total } \\
\text { Events }\end{array}$ & $\begin{array}{c}\text { Selected } \\
\text { Cases }\end{array}$ & Median & $\begin{array}{c}\text { Median } \\
(\mathrm{Log})\end{array}$ & $\begin{array}{c}\text { Var } \\
(\mathrm{Log})\end{array}$ & $\begin{array}{c}\text { Skew } \\
(\mathrm{Log})\end{array}$ & $\begin{array}{c}\text { SE } \\
\text { Skew } \\
(\mathrm{Log})\end{array}$ & $\begin{array}{c}\text { Test } \\
\text { Norm. } \\
\text { p-vag) }\end{array}$ & $\begin{array}{c}\text { Median } \\
\text { Ratio }\end{array}$ \\
\hline Commercial Composite & 92 & 82 & 16.98 & 1.230 & 0.083 & -0.038 & 0.266 & 0.117 & 1.62 \\
Commercial First Flush & 92 & 82 & 27.48 & 1.439 & 0.120 & 0.343 & 0.266 & 0.035 & \\
Industrial Composite & 84 & 76 & 25.00 & 1.398 & 0.079 & 0.184 & 0.276 & 0.344 & 1.24 \\
Industrial First Flush & 84 & 76 & 30.97 & 1.491 & 0.166 & -0.014 & 0.276 & 0.007 & \\
Institutional Composite & 18 & 7 & 16.98 & 1.230 & 0.083 & -0.228 & 0.794 & 0.167 & 0.94 \\
Institutional First Flush & 18 & 7 & 16.00 & 1.204 & 0.047 & 0.954 & 0.794 & 0.555 & \\
Open Space Composite & 30 & 22 & 5.14 & 0.711 & 0.103 & 0.085 & 0.491 & 0.252 & 0.78 \\
Open Space First Flush & 30 & 22 & 4.00 & 0.602 & 0.120 & 1.005 & 0.491 & 0.015 & \\
Residential Composite & 144 & 108 & 11.99 & 1.079 & 0.082 & -0.677 & 0.233 & 0 & 1.33 \\
Residential First Flush & 144 & 108 & 16.00 & 1.204 & 0.087 & 0.023 & 0.233 & 0.256 & \\
All Landuses Composite & 368 & 295 & 15.00 & 1.176 & 0.116 & -0.268 & 0.142 & 0 & 1.33 \\
All Landuses First Flush & 368 & 295 & 20.00 & 1.301 & 0.167 & 0.009 & 0.142 & 0 & 0 \\
\hline
\end{tabular}

\begin{tabular}{lccccc}
\hline Total Copper & $\begin{array}{c}\text { Mann Wittn } \mathrm{p}- \\
\text { value }\end{array}$ & Fligner Policello & $\begin{array}{c}\text { Normality for } \mathrm{t} \text { - } \\
\text { test } \mathrm{p} \text {-value }\end{array}$ & $\begin{array}{c}\text { Paired } \\
t \text {-test }\end{array}$ & Result \\
\hline Commercial & $\mathrm{N} / \mathrm{A}$ & $\mathrm{U}=5.160 ; \mathrm{P}=0$ & 0.001 & $\mathrm{~N} / \mathrm{A}$ & Different (first flush) \\
Industrial & N/A & $\mathrm{U}=1.864 ; \mathrm{P}=0.03$ & 0.329 & 0.012 & Different \\
Institutional & 0.5224 & $\mathrm{U}=0.665 ; \mathrm{P}>0.099$ & 0.318 & 0.029 & Same (no first flush) \\
Open Space & N/A & $\mathrm{U}=0.846 ; \mathrm{P}=0.19$ & 0.074 & 0.337 & Same \\
Residential & N/A & $\mathrm{U}=4.029 ; \mathrm{P}=0$ & 0.292 & 0 & Different \\
All Landuses & N/A & $\mathrm{U}=5.146 ; \mathrm{P}=0$ & 0 & N/A & Different \\
\hline
\end{tabular}


Table 15-5 cont'd Results of preliminary statistical analysis for Total Lead.

\begin{tabular}{|c|c|c|c|c|c|c|c|c|c|}
\hline Total Lead $(\mu g / L)$ & $\begin{array}{l}\text { Total } \\
\text { Events }\end{array}$ & $\begin{array}{c}\text { Selected } \\
\text { Cases }\end{array}$ & Median & $\begin{array}{l}\text { Media } \\
\mathrm{n}(\log )\end{array}$ & $\begin{array}{c}\text { Var } \\
(L \circ g)\end{array}$ & $\begin{array}{l}\text { Skew } \\
\text { (Log) }\end{array}$ & $\begin{array}{c}\text { SE } \\
\text { Skew } \\
\text { (Log) }\end{array}$ & $\begin{array}{c}\text { Test } \\
\text { Norm. } \\
\text { (Log) } \\
\text { p-value }\end{array}$ & $\begin{array}{c}\text { Median } \\
\text { Ratio }\end{array}$ \\
\hline Commercial Composite & 89 & 83 & 16.98 & 1.230 & 0.062 & 0.075 & 0.264 & 0.824 & \multirow{2}{*}{1.65} \\
\hline Commercial First Flush & 89 & 83 & 27.99 & 1.447 & 0.123 & 0.070 & 0.264 & 0.476 & \\
\hline Industrial Composite & 84 & 71 & 16.98 & 1.230 & 0.160 & 0.527 & 0.285 & 0.081 & \multirow{2}{*}{1.41} \\
\hline Industrial First Flush & 84 & 71 & 23.99 & 1.380 & 0.240 & 0.319 & 0.285 & 0.608 & \\
\hline Institutional Composite & 18 & 13 & 7.00 & 0.845 & 0.082 & 0.675 & 0.616 & 0.158 & \multirow{2}{*}{2.28} \\
\hline Institutional First Flush & 18 & 13 & 15.96 & 1.203 & 0.051 & 0.128 & 0.616 & 0.228 & \\
\hline Open Space Composite & 31 & 16 & 5.00 & 0.699 & 0.381 & -0.303 & 0.564 & 0.199 & \multirow{2}{*}{0.90} \\
\hline Open Space First Flush & 31 & 16 & 4.48 & 0.651 & 0.346 & -0.466 & 0.564 & 0.563 & \\
\hline Residential Composite & 140 & 93 & 8.79 & 0.944 & 0.231 & 0.084 & 0.250 & 0.884 & \multirow{2}{*}{1.48} \\
\hline Residential First Flush & 140 & 93 & 13.00 & 1.114 & 0.204 & 0.130 & 0.250 & 0.105 & \\
\hline All Landuses Composite & 364 & 278 & 13.00 & 1.114 & 0.198 & -0.365 & 0.146 & 0.006 & \multirow{2}{*}{1.50} \\
\hline All Landuses First Flush & 364 & 278 & 19.50 & 1.290 & 0.239 & -0.307 & 0.146 & 0.401 & \\
\hline
\end{tabular}

\begin{tabular}{lccccc}
\hline Total Lead & Mann Wittn. p-value & Fligner Policello & $\begin{array}{c}\text { Normality for t-test } \mathrm{p} \text { - } \\
\text { value }\end{array}$ & $\begin{array}{c}\text { Paired } \\
t \text {-test }\end{array}$ & Result \\
\hline Commercial & 0 & $\mathrm{U}=5.256 ; \mathrm{P}=0$ & 0.794 & 0 & Different \\
Industrial & 0.083 & $\mathrm{U}=1.742 ; \mathrm{P}=0.04$ & 0.167 & 0.016 & Different \\
Institutional & 0.004 & $\mathrm{U}=3.973 ; \mathrm{P}=0$ & 0.680 & 0.000 & Different \\
Open Space & 0.771 & $\mathrm{U}=0.292 ; \mathrm{P}=0.39$ & 0.008 & 0.578 & Same \\
Residential & 0.012 & $\mathrm{U}=2.59 ; \mathrm{P}=0$ & 0.014 & N/A & Different \\
All Landuses & $\mathrm{N} / \mathrm{A}$ & $\mathrm{U}=4.77 ; \mathrm{P}=0$ & 0 & N/A & Different \\
\hline
\end{tabular}


Table 15-5 cont'd Results of preliminary statistical analysis for Total Nickel.

\begin{tabular}{lccccccccc}
\hline \multicolumn{1}{c}{ Total Nickel $(\mu \mathrm{g} / \mathrm{L})$} & $\begin{array}{c}\text { Total } \\
\text { Events }\end{array}$ & $\begin{array}{c}\text { Selected } \\
\text { Cases }\end{array}$ & Median & $\begin{array}{c}\text { Median } \\
(\mathrm{Log})\end{array}$ & $\begin{array}{c}\text { Var } \\
(\mathrm{Log})\end{array}$ & $\begin{array}{c}\text { Skew } \\
(\mathrm{Log})\end{array}$ & $\begin{array}{c}\text { SE } \\
\text { Skew } \\
(\mathrm{Log})\end{array}$ & $\begin{array}{c}\text { Test } \\
\text { Norm. } \\
\text { (Log) } \\
\text { p-value }\end{array}$ & $\begin{array}{c}\text { Median } \\
\text { Ratio }\end{array}$ \\
\hline Commercial Composite & 47 & 23 & 5.00 & 0.699 & 0.094 & 0.660 & 0.481 & 0.254 & 2.40 \\
Commercial First Flush & 47 & 23 & 11.99 & 1.079 & 0.134 & -0.606 & 0.481 & 0.523 & \\
Industrial Composite & 51 & 22 & 7.00 & 0.845 & 0.106 & -0.293 & 0.491 & 0.229 & 1.00 \\
Industrial First Flush & 51 & 22 & 7.00 & 0.845 & 0.197 & 0.605 & 0.491 & 0.228 & \\
Residential Composite & 83 & 18 & 7.48 & 0.874 & 0.094 & 0.152 & 0.536 & 0.814 & 1.20 \\
Residential First Flush & 83 & 18 & 8.99 & 0.954 & 0.115 & 1.551 & 0.536 & 0.048 & \\
All Landuses Composite & 213 & 64 & 6.00 & 0.778 & 0.104 & 0.146 & 0.299 & 0.161 & 1.50 \\
All Landuses First Flush & 213 & 64 & 8.99 & 0.954 & 0.147 & 0.322 & 0.299 & 0.443 & \\
\hline
\end{tabular}

\begin{tabular}{lccccc}
\hline Total Nickel & $\begin{array}{c}\text { Mann Wittn. p- } \\
\text { value }\end{array}$ & Fligner Policello & $\begin{array}{c}\text { Normality for } \mathrm{t} \text { - } \\
\text { test } \mathrm{p} \text {-value }\end{array}$ & $\begin{array}{c}\text { Paired } \\
\mathrm{t} \text {-test }\end{array}$ & Result \\
\hline Commercial & 0.006 & $\mathrm{U}=3.005 ; \mathrm{P}=0$ & 0.128 & 0.002 & Different (first flush) \\
Industrial & 0.715 & $\mathrm{U}=0.365 ; \mathrm{P}=0.36$ & 0.203 & 0.484 & Same (no first flush) \\
Residential & $\mathrm{N} / \mathrm{A}$ & $\mathrm{U}=1.143 ; \mathrm{P}=0.13$ & 0.512 & 0.098 & Same \\
All Landuses & 0.014 & $\mathrm{U}=2.539 ; \mathrm{P}=0.01$ & 0.367 & 0.001 & Different \\
\hline
\end{tabular}


Table 15-5 cont'd Results of preliminary statistical analysis for Total Zinc.

\begin{tabular}{lccccccccc}
\hline \multicolumn{1}{c}{ Total Zinc $(\mu \mathrm{g} / \mathrm{L})$} & $\begin{array}{c}\text { Total } \\
\text { Events }\end{array}$ & $\begin{array}{c}\text { Selected } \\
\text { Cases }\end{array}$ & Median & $\begin{array}{c}\text { Median } \\
(\mathrm{Log})\end{array}$ & $\begin{array}{c}\text { Var } \\
(\mathrm{Log})\end{array}$ & $\begin{array}{c}\text { Skew } \\
(\mathrm{Log})\end{array}$ & $\begin{array}{c}\text { SE } \\
\text { Skew } \\
(\mathrm{L} \text { og })\end{array}$ & $\begin{array}{c}\text { Test } \\
\text { Norm. } \\
(\mathrm{Log}) \\
\text { p-value }\end{array}$ & $\begin{array}{c}\text { Median } \\
\text { Ratio }\end{array}$ \\
\hline Commercial Composite & 90 & 90 & 149.97 & 2.176 & 0.089 & -1.359 & 0.254 & 0 & 1.93 \\
Commercial First Flush & 90 & 90 & 289.07 & 2.461 & 0.139 & -0.374 & 0.254 & 0.647 & \\
Industrial Composite & 83 & 83 & 225.94 & 2.354 & 0.184 & 0.828 & 0.264 & 0 & 1.54 \\
Industrial First Flush & 83 & 83 & 348.34 & 2.542 & 0.135 & -0.181 & 0.264 & 0.930 & \\
Institutional Composite & 18 & 18 & 304.79 & 2.484 & 0.114 & -0.227 & 0.536 & 0.878 & 2.48 \\
Institutional First Flush & 18 & 18 & 755.09 & 2.878 & 0.133 & -0.696 & 0.536 & 0.055 & \\
Open Space Composite & 21 & 21 & 20.00 & 1.301 & 0.165 & 0.081 & 0.501 & 0.073 & 1.25 \\
Open Space First Flush & 21 & 21 & 25.00 & 1.398 & 0.075 & -0.242 & 0.501 & 0.295 & \\
Residential Composite & 136 & 136 & 69.34 & 1.841 & 0.114 & 0.824 & 0.208 & 0.003 & 1.58 \\
Residential First Flush & 136 & 136 & 109.90 & 2.041 & 0.200 & -0.232 & 0.208 & 0.014 & \\
All Landuses Composite & 350 & 350 & 125.89 & 2.100 & 0.216 & 0.121 & 0.130 & 0.001 & 1.59 \\
All Landuses First Flush & 350 & 350 & 199.99 & 2.301 & 0.268 & 0.437 & 0.130 & 0.020 & \\
\hline
\end{tabular}

\begin{tabular}{lccccc}
\hline Total Zinc & $\begin{array}{c}\text { Mann Wittn } \mathrm{p}- \\
\text { value }\end{array}$ & Fligner Policello & $\begin{array}{c}\text { Normality for t-test } \mathrm{p}- \\
\text { value }\end{array}$ & $\begin{array}{c}\text { Paired } \\
t \text {-test }\end{array}$ & Result \\
\hline Commercial & N/A & $\mathrm{U}=6.156 ; \mathrm{P}=0$ & 0 & N/A & Different \\
Industrial & N/A & $\mathrm{U}=2.087 ; \mathrm{P}=0.02$ & 0.006 & N/A & Different \\
Institutional & 0.007 & $\mathrm{U}=3.1 ; \mathrm{P}=0$ & 0.498 & 0 & Different \\
Open Space & N/A & $\mathrm{U}=0.023 ; \mathrm{P}=0.49$ & 0.667 & 0.977 & Same \\
Residential & N/A & $\mathrm{U}=4.329 ; \mathrm{P}=0$ & 0 & N/A & Different \\
All Landuses & N/A & $\mathrm{U}=5.374 ; \mathrm{P}=0$ & 0 & N/A & Different \\
\hline
\end{tabular}


Table 15-5 cont'd Results of preliminary statistical analysis for TSS.

\begin{tabular}{lcccccccccc}
\hline \multicolumn{1}{c}{ TSS (mg/L) } & $\begin{array}{c}\text { Total } \\
\text { Events }\end{array}$ & $\begin{array}{c}\text { Selected } \\
\text { Cases }\end{array}$ & Median & $\begin{array}{c}\text { Median } \\
(\log )\end{array}$ & $\begin{array}{c}\text { Var } \\
(\mathrm{Log})\end{array}$ & $\begin{array}{c}\text { Skew } \\
(\mathrm{Log})\end{array}$ & $\begin{array}{c}\text { SE } \\
\text { Skew } \\
(\mathrm{Log})\end{array}$ & $\begin{array}{c}\text { Test } \\
\text { Norm. } \\
(\mathrm{Log}) \\
\text { p-value }\end{array}$ & $\begin{array}{c}\text { Median } \\
\text { Ratio }\end{array}$ \\
\hline Commercial Composite & 90 & 90 & 54.95 & 1.740 & 0.106 & 0.168 & 0.254 & 0.730 & 1.85 \\
Commercial First Flush & 90 & 90 & 101.86 & 2.008 & 0.200 & -0.508 & 0.254 & 0.016 & \\
Industrial Composite & 83 & 83 & 66.07 & 1.820 & 0.186 & -0.021 & 0.264 & 0.336 & 0.97 \\
Industrial First Flush & 83 & 83 & 63.97 & 1.806 & 0.374 & -0.157 & 0.264 & 0.055 & \\
Institutional Composite & 18 & 18 & 16.48 & 1.217 & 0.110 & -0.176 & 0.536 & 0.122 & 2.12 \\
Institutional First Flush & 18 & 18 & 34.99 & 1.544 & 0.145 & -0.164 & 0.536 & 0.846 & \\
Open Space Composite & 32 & 32 & 21.98 & 1.342 & 0.424 & -0.526 & 0.414 & 0.511 & 0.95 \\
Open Space First Flush & 32 & 32 & 20.89 & 1.320 & 0.563 & -0.126 & 0.414 & 0.847 & \\
Residential Composite & 144 & 144 & 37.50 & 1.574 & 0.217 & -0.033 & 0.202 & 0.282 & 1.84 \\
Residential First Flush & 144 & 144 & 69.02 & 1.839 & 0.302 & -0.267 & 0.202 & 0.533 & \\
All Landuses Composite & 372 & 372 & 44.36 & 1.647 & 0.226 & -0.381 & 0.126 & 0.008 & 1.60 \\
All Landuses First Flush & 372 & 372 & 70.96 & 1.851 & 0.335 & 0.457 & 0.126 & 0 & \\
\hline
\end{tabular}

\begin{tabular}{lccccc}
\hline \multicolumn{1}{c}{ TSS } & $\begin{array}{c}\text { Mann Wittn. p- } \\
\text { value }\end{array}$ & Fligner Policello & $\begin{array}{c}\text { Normality for t- } \\
\text { test p-value }\end{array}$ & $\begin{array}{c}\text { Paired } \\
\text { t-test }\end{array}$ & Result \\
\hline Commercial & N/A & $\mathrm{U}=5.345 ; \mathrm{P}=0$ & 0.014 & N/A & Different (first flush) \\
Industrial & 0.627 & $\mathrm{U}=0.483 ; \mathrm{P}=0.31$ & 0.222 & 0.432 & Same (no first flush) \\
Institutional & 0.007 & $\mathrm{U}=3.095 ; \mathrm{P}=0$ & 0.309 & 0.001 & Different \\
Open Space & 0.706 & $\mathrm{U}=0.39 ; \mathrm{P}=0.35$ & 0.183 & 0.614 & Same \\
Residential & N/A & $\mathrm{U}=4.89 ; \mathrm{P}=0$ & 0 & N/A & Different \\
All Landuses & N/A & $\mathrm{U}=6.65 ; \mathrm{P}=0$ & 0 & N/A & Different \\
\hline
\end{tabular}

